\title{
STRUCTURE AND PROCESS, POLITICS AND POLICY: ADMINISTRATIVE ARRANGEMENTS AND THE POLITICAL CONTROL OF AGENCIES
}

\author{
Matthew D. McCubbins, ${ }^{*}$ Roger G. Noll, ${ }^{* *}$ and Barry R. Weingast ${ }^{* * *}$
}

$I^{2}$

N 1977, Congress substantially revised the Clean Air Act, ${ }^{1}$ the nation's flagship legislation on environmental policy. Many changes were considered, and among those that Congress adopted was an intricate redefinition of the procedures to be used by the Environmental Protection Agency (EPA) in inaking rules. ${ }^{2}$ The Clean Air Act Amendments of 1970 (1970 Amendinents), which had inoved responsibility for air pollution regulation from the Public Health Service in the Departinent of Health, Education, and Welfare (HEW) to the newly minted EPA, set up the EPA's rulenaking procedures as "informal" witl few procedural requirenents and considerable decisional flexibility. ${ }^{3}$ After extensive debate in both the 94th and 95th Congresses, ${ }^{4}$ Congress changed this to a new liybrid process (more formal than "informal ruleınaking" but less formal than "formal ruleinaking") that requires a more elaborate written record and a clearer statement of agency intentions and of the bases for its decisions. ${ }^{5}$

As a reading of the committee reports and floor debates about these and similar proposals makes clear, legislators regard the clioice of administrative structure and process as vitally important. ${ }^{6}$ The legislative history of admin-

* Associate Professor, Department of Political Science, University of California, San Diego.

The authors thank Sharyn O'Halloran for her assistance on this Article. Mr. McCubbims and Mr. Weingast acknowledge the support of the National Science Foundation under grants SES-8811022 and SES-8617516.

** Departnient of Economics, Stanford University.

*** Senior Researcli Fellow, Hoover Institution, Stanford University.

1 Clean Air Act Amendnients of 1977, Pub. L. No. 95-95, 91 Stat. 685 (codified as amended at 42 U.S.C. $\$ \S 7401-7642$ (1982 \& Supp. IV 1986)).

2 See id. § 305, 91 Stat. at 774 (codified at 42 U.S.C. $\$ 7607$ (d) (1982)); see also H.R. Rep. No. 294, 95th Cong., 1st Sess. 27, reprinted in 1977 U.S. Code Cong. \& Admin. News 1077, 1105 ("This section establishes compreliensive procedures for most informal rulemaking under the Clean Air Act in heu of the Administrative Procedure Act.").

3 Clean Air Act Amendments of 1970, Pub. L. No. 91-604, § 3, 84 Stat. 1676, 1677 (codified as amended at 42 U.S.C. $\$ 7607$ (d) (1982)).

4 See infra notes 121-56 and accompanying text.

5 See Clean Air Act Amendments of 1977, Pub. L. No. 95-95, § 302, 91 Stat. 685, 770 (codified at 42 U.S.C. $\$ 7607$ (d) (1982)).

6 As used here, "process" refers to the rules and standards that apply to policy decisions by an agency and guide judicial review, whereas "structure" refers to the allocation of resources 
istrative reforms contains discussion of two issues that also surface in the scholarly hiterature. As emphasized by public administration and organization theory scholars, legislators are concerned about agency efficiency in collecting and evaluating relevant information to guide administrative decisions, and in implementing these decisions. ${ }^{7}$ Also, as emphasized by scholars of admimistrative law, legislators debate fairness and the protection of individual rights when considering alternative institutional arrangements. ${ }^{8}$

In addition, the choice of structure and process is guided by political concerns. Specifically, legislators see the choice of admimistrative structures and processes as miportant in assuring that agencies produce policy outcoines that legislators deem satisfactory. Structure and process are regarded as miportant im determining the relative influence of different imterests in the decisionmaking process, as well as the balance of influence between the President and Congress. The purpose of this Article is to contribute to the positive political theory of the structure and process of administrative agencies.

In a previous article, ${ }^{9}$ we explained our view of low elected political leaders design admimistrative procedures. We asserted that admimistrative procedures are one means of guiding agencies to make decisions that are consistent witl the preferences of the legislative coalition (imcludimg the President) that succeeded in passing the agency's enabling legislation, but without requiring the members of that coalition to monitor, or even be aware of, the nature of the agency's actions. ${ }^{10}$ This Article advances the discussion in three ways.

First, we explicitly take into account that elected political officials inay differ over their desired policy outcomes. In so doing, this Article more clearly identifies the kinds of internal coalitional problems that structure and process might be expected to solve. Specifically, structure and process can be viewed as embodying an ex ante agreement among legislators and the

and decisional authority among agencies and within an agency. Examples of process are rules of standing and evidence and the assignment of burdens of proof, whereas a flow chart depicting the sequence of actions and identifying the associated actors would reveal examples of structure. Most often, structure refers to "veto gates"-those points in the process where policy can be killed-and which actors control thein.

7 See, e.g., J. Charlesworth, Governmental Adıninistration 45-86 (1951); J. Millett, Governinent and Public Administration: The Quest for Responsible Performance 63-250 (1963); J. Pfiffner \& R. Presthus, Public Administration 443-536 (1960); J. Shafritz \& A. Hyde, Classics of Public Administration (1987); J. Shafritz \& J. Ott, Classics of Organization Theory (1987).

8 See, e.g., J. Sliafritz \& A. Hyde, supra note 7; Berger, Administrative Law After Forty Years, 33 Fed. B. News J. 297 (1986).

9 McCubbius, Noll \& Weingast, Administrative Procedures as Instruments of Pohtical Control, 3 J.L. Econ. \& Org. 243 (1987).

10 Id. at 253-55. 
President that limits the ability of each to engage in ex post opportunistic behavior. Because each has an incentive to influence the agency to inake policies that are not consistent witl the coalition's legislative agreennent, all can be better off if they employ means to limit their own opportunism.

Second, this Article identifies and analyzes a key problein with the use of traditional methods of oversight and rewards or punishments to assure agency compliance with the policy preferences of the winning coalition. Specifically, this is the problem of "history dependence" or "reactive enforcement" in legislative processes. For reasons elaborated below, the outcome of a legislative atteinpt to rectify an act of noncompliance by an agency will not, in general, reproduce the pohicy outcome that was souglit by the winning coalition, even if the preferences of the members of the legislative body remain unclianged. Thus, effective political control of an agency requires ex ante constraints on the agency (thiat is, a means of restricting the agency's decisioninaking before it actually makes policy clioices), one source of which is mainpulation of its structure and process.

Third, to illustrate the principal lines of argument, this Article traces the organizational and procedural history of air pollution regulation in the United States. The discussion of air pollution regulation is not intended to be comprehensive; imdeed, several excellent books have been written on the subject. $^{11}$ Instead, we provide examples of structural and procedural reforins considered by Congress, many of whicli were never enacted, that exemplify our general conceptual model.

\section{Structure, Process, ANd Bureaucratic Compliance}

In examining the problem of assuring agency comphance witl the desires of the political coalition enacting and overseeing legislation, we make use of three related theoretical advances of the 1970s: principal-agent theory, ${ }^{12}$ perfect equilibrium, ${ }^{13}$ and structure-mduced equilibriun.$^{14}$

Principal-agent theory applies to circunistances when one person (the principal) arranges for another (the agent) to take an action that is beneficial

11 See, e.g., B. Ackerman \& W. Hassler, Clean Coal/Dirty Air (1981); R. Melnick, Regulation and the Courts (1983).

12 See Holmstrom, Moral Hazard and Observability, 10 Bell J. Econ. 74 (1979) (considering the role of imperfect information and moral hazard in principal-agent relationships).

13 See Selten, Reexamination of the Perfectness Concept for Equilibrium Points in Extensive Games, 4 Int'I J. Game Theory 25 (1975) (discussing the concept of a perfect equilibrium where the equilibrium is robust to slight inistakes).

14 See Shepsle \& Wenigast, Structure-Induced Equilibrium and Legislative Clroice, 37 Pub. Clroice 503 (1981) (explaining the properties of legislative institutions necessary for the existence of equilibrium and offering an alternative view of institutions based upon majority rule). 
to the principal but costly to the agent, under circumstances when the principal cannot perfectly and costlessly enforce an ex ante promise by the agent to act in the best interests of the principal. For the purposes of this Article, the principal in the problem of bureaucratic comphance is the coalition enacting a new pohicy and estabhishing a structure and process for miplementing it. The agent is the bureau that is to implement the policy.

The standard solution to a principal-agent problein is: first, for the two actors to agree on a compensation schedule that the principal will implement on the basis of the outcome of the agent's actions; and second, for the principal to engage in costly monitoring to enable the principal to assess the agent's performance. The counterpart in political processes is oversight: investigations into the perfornance of an agency, soinetmies in the context of the annual budgetary process, and occasionally as part of the reauthorization of an agency's programs. In addition, botli Congress and the President have "watchdog" agencies to inonitor agency perforinance, such as the Office of Managenient and Budget and the General Accounting Office.

An important disadvantage of the investigative oversight process is its cost. The tine of pohtical officials and their staffs is a valuable resource, and normal oversight consumes it. An alternative is to set up a systein in which someone else (that is, a third party outside of the principal-agent diad) monitors the agent and reports acts of noncompliance. In political processes, the object of legislation is to deliver benefits to the policy's target group. If politicians make it easy for this group to detect and report noncomphance, they need not use their own resources in nionitoring the agency. Instead, a pohtician who was a meniber of the coalition that enacted a program can rely on "fire alarms" sounded by the targeted beneficiaries as a inechanism to trigger fornal investigations and/or legislative responses to nonconiphance. ${ }^{15}$

A fire alarm converts the oversight job of a politician froin active nuonitor to reactive servant of affected constituencies, and fits nicely with the observation that the role of a inodern legislator is more like that of an ombudsman than a policymaker. ${ }^{16}$ But the effectiveness of the fire alarm depends on the credibility of pohitical officials when they threaten to punish an agency that is not coinplying with the wishes of its overseers. That is, if an agency prefers to adopt a pohicy that differs significantly froin the preference of the coalition that enacted its program, it can be dissuaded froin domg so only if its pohtical overseers are able to undo its actions and/or punish it.

15 See McCubbins \& Schwartz, Congressional Oversight Overlooked: Police Patrols Versus Fire Alarms, 28 Am. J. Pol. Sci. 165 (1984).

16 See M. Fiorina, Congress: Keystone of the Washington Establishment $42-49$ (1977); Fiorina \& Noll, Majority Rule Models and Legislative Elections, 41 J. Pol. 1081, 1101 (1979). 
For several reasons, agencies may not regard threats of punishment as credible, especially if the threats are from Congress. Most of these reasons are discussed in our earlier article, ${ }^{17}$ and we will not reprise thein here. Instead, we focus on two points. First, the President's role in appointing the top administrators of agencies offers him an advantage in influencing policy, especially for agencies in the executive branch where the top administrators serve at the pleasure of the President. Hence, we expect that an enduring theme in Congress will be to build in protections against undue influence by the President. Second, Congress and the President cannot rely on their ability to correct a noncomplying decision by an agency through legislative action, whether by changing its mandate, its structure, its procedures, or its budget. The reason is to be found in the theory of structure-induced equilibrium and, in particular, in the dependence of legislative processes on the details of the status quo that legislative action is supposed to alter.

\section{A. Potential Manipulation by the Agency}

To see why Congress and the President cannot rely solely on the threat of new legislation to force agency comphance, we consider the following example. ${ }^{18}$ Although our exainple is very simple, it illustrates the general proposition that different status quo policies produce different legislative outcoines.

To begin, we assume that the game between politicians and agencies is played only once-that is, the agency chooses a pohicy that the politicians can either accept or reject by passing new legislation. Consider a three-person unicameral legislative body picking a policy in a two-dimensional policy space, as depicted below in Figure 1. Each member is assumed to have common knowledge about the structure of the gaine and the preferences of all other players. Anticipating the analysis of air pollution regulation in Part II of this Article, ${ }^{19}$ the dimensions could be the stringency of environmental policy (for exainple, how inuch pollution to abate) and the extent to which antipollution policy will be structured to advantage estabhished (as opposed

17 See McCubbins, Noll \& Weingast, supra note 9, at 248-53.

18 The example that follows is in the spirit of the model developed by Hammond, Hill, and Miller and provides the analysis necessary to understand the problem of manipulation of politicians by their agents. As we show below, however, the appropriate interpretation of this model is that it characterizes the problem to be solved, not the actual pattern of interaction between an agency and politicians. See T. Hammond, J. Hill \& G. Miller, Presidential Appointment of Bureau Chiefs and the "Congressional Control of Administration" Hypothesis (March 30, 1986) (unpublished paper delivered at a meeting of the American Pohtical Science Association).

19 See infra notes 36-148 and accompanying text. 
to entering) production facilities. The points labeled 1,2 , and $C$ represent the most-preferred policies (ideal points) of the three legislators.

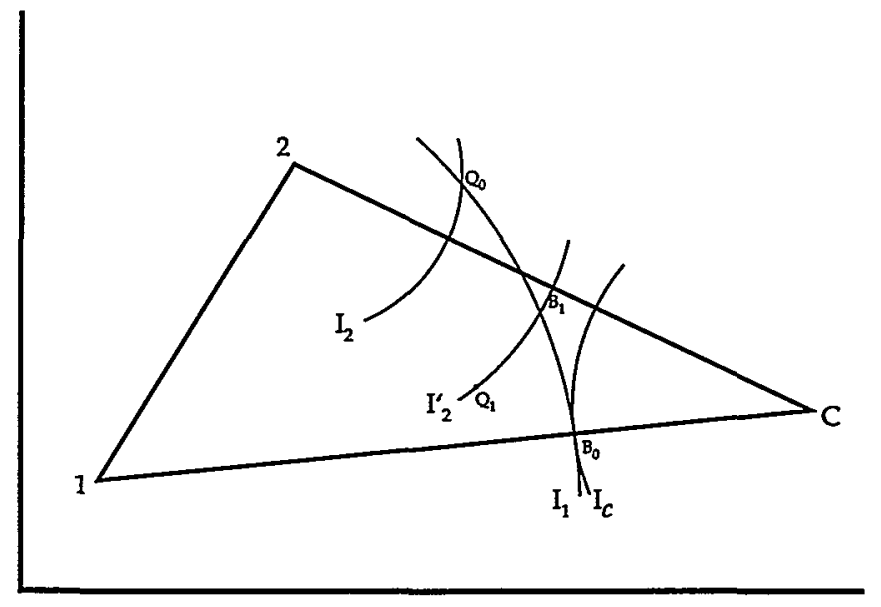

Figure 1

We also assume that the loss of welfare to eacli member as the policy moves away from that person's ideal point is proportional to the distance from tliat ideal point (that is, their indifference contours can be represented as circles). If this is the case, the triangle defined by the lines connecting the three ideal points contains all of the Pareto optimal outcoines-that is, the policy clioices that cannot be changed witliout making one of the three meinbers worse off. The point $Q_{o}$ represents the status quo, which is the policy that will be in place if the legislature takes no action. Finally, member $C$ is a one-person cominittee tliat has jurisdiction over the policy under consideration. We assume for simplicity tliat member $C$ possesses a monopoly on making proposals to cliange the status quo, and that these proposals are considered by the legislature (that is, $C$ togetler witlı meinbers 1 and 2) under a "closed rule" wherein the members simply vote for $C$ 's proposal or the status quo. ${ }^{20}$

Assuming that eacl member seeks to move policy closer to his or lier ideal point, the best strategy available to inember $C$ is to propose an alternative that comes as close to point $C$ as possible while still obtaining the support of at least one other legislator, tliereby defeating the status quo by a vote of at

20 Closed rules (i.e., where a member's ability to offer amendments to a bill on the floor is restricted) are not common in the House of Representatives and are virtually never adopted in the Senate. Although the details of the rules pertaining to a bill clearly influence the nature of legislative outcomes, the basic processes at work are similar for the closed rule and produce qualitatively similar results. See Weingast, Floor Behavior in Congress: Committee Power Under the Open Rule, 83 Am. Pol. Sci. Rev. (forthcoming Sept. 1989). 
least two to one. $C$ can find this point by locating the points in the triangle that either 1 or 2 regards as equally desirable as the status quo. We have drawn indifference contours $\left(I_{1}\right.$ and $\left.I_{2}\right)$ for both legislators 1 and 2 that pass through status quo point $Q_{0}$. As is apparent froin inspection, point $B_{0}$ is the best alternative for ineinber $C$. If $C$ proposes a bill shightly closer to inember $I$ than point $B_{0}$, the proposal will defeat $Q_{0}$ by a vote of two to one. Meinbers 1 and $C$, therefore, can be regarded as having formed a coalition to enact $B_{0}$, which then becoines the new status quo.

The problein of a noncomplying agency is depicted on the diagram as follows. Suppose that the agency implements not $B_{0}$ but $Q_{l}$, which thus becoines the new status quo point. Then, in the next session of the legislature, the best proposal that $C$ can hope to enact is bill $B_{1}$, which is passed by a new coalition between $C$ and 2. ( $I_{2}{ }^{\prime}$ is the indifference contour for legislator 2 when the status quo point is $Q_{1}$.) Although $B_{1}$ is preferred to $B_{0}$ by ineinber 2, meinbers $I$ and $C$ are worse off than at outcoine $B_{0}$. Moreover, by shight modifications in the diagram, one can depict circuinstances in which agency noncounphiance makes any given meinber, or any combination of two members, worse off than at outcoine $B_{0}$.

The important insight from this example is that, even with perfect inonitoring of agency noncoinpliance, no legislative reinedy is available to the original coalition that will restore its original agreement. ${ }^{21}$ By establishing a new status quo, a noncomplying agency has broken apart the coalition that gave rise to its initial mandate. Of course, this phenomenon is quite general-agency noncoinphance in other directions away froin $B_{0}$ inflicts a different pattern of gains and losses and causes different coalitional responses. Hence, each party, including the legislator who is not a member of the original coalition, stands some chance of loss from agency noncoinpliance. If legislators are risk averse, ${ }^{22}$ unpredictability in the nature of agency noncoinphance will be regarded by all as undesirable. Thus, they will all have an incentive to develop soine ineans of assuring coinphiance other than correction of errors after they are observed.

So far, our analysis has focused entirely on meinbers of a legislature, but with a few changes it can be altered to represent the policy tug-of-war among the House, the Senate, and the President. For purposes of exposition, we

21 The unqualified nature of this conclusion depends on the one-shot assumption noted above. When the relationship is repeated, more complicated patterns of interaction can arise.

22 Legislators are likely to behave as if they are risk averse, even if they are personally risk neutral, if their constituents purish unpredictable policy choices or their reelection probability is nearly unity. See L. Colien \& R. Noll, Intertemporal Policy Preferences of a Legislator (Center for Economic Policy Research, Stanford Umversity 1984). See generally, D. Mayhew, Congress: The Electoral Connection 13-17 (1974) (explaining how legislative behavior is affected by the quest for reelection). 
will ignore the problem of intrachamber choice depicted in Figure 1, and assume that each legislative body is homogeneous, with a unique collective ideal policy and set of indifference curves. The point of this analysis will be to illustrate the significance of the quite different institutional rules governing policy formation among the two branches of the legislature and the President. The key points for our analysis are that the House and Senate bargain over the contents of a legislative proposal, and that the President has veto power. We will ignore the possibility of a veto override in order to retain simplicity in the exanple.

Fignre 2 depicts the ideal points of the House $(H)$, Senate $(S)$, and President $(P)$, the status quo point $\left(Q_{0}\right)$, and the indifference curve of each that

\section{Figure 2}

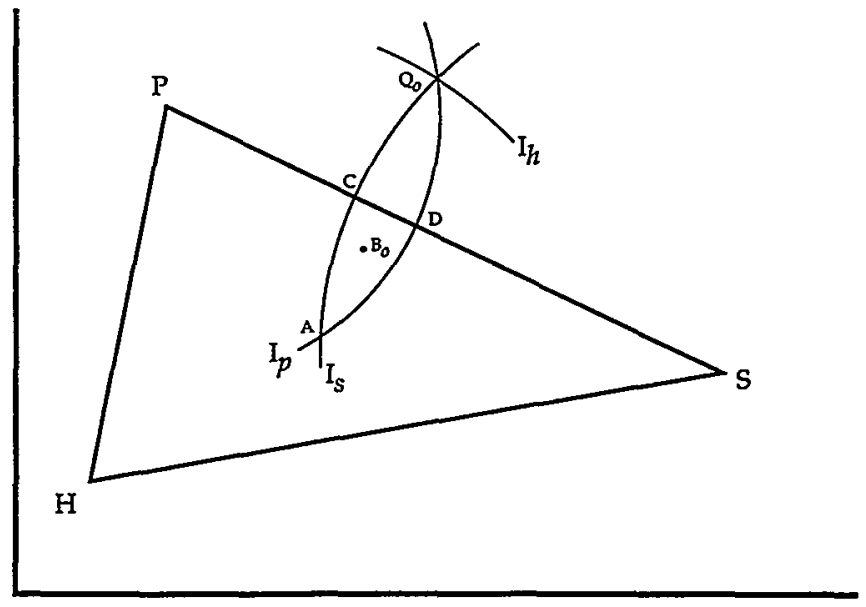

passes through $Q_{0}$. The lens-shaped figure defined by points $Q_{0}, A, C$, and $D$ defines the possible policy outcomes that are preferred by all three. Because each has a veto (thiat is, the bill inust pass botli cliambers and be signed by the President), the new policy outcome inust be located within this "lens." Point $D$ represents the best possible feasible outconie for the Senate, Point $A$ is the best that the House can do, and Point $C$ is the most desirable feasible outcoine for the President. The half-lens defined by points $A, C$, and $D$ contanis all possible final bills. ${ }^{23}$ The bargaining process and the strength of the

23 The proof of this assertion is as follows: (I) for any proposal outside of the triangle $P H S$ there are proposals inside the triangle that make all three members better off (recall that PHS contains all Pareto optimal policies); (2) for any proposal within PHS, but outside the halflens, at least one member is worse off than if $Q_{0}$ is retained, and that member will veto the proposal. 
three participants will determine which point within the figure $A C D$ will be selected. For example, if the House and Senate can convince the President that no second bill will emerge from them if their proposal is vetoed, then they can bargain over points along the President's indifference curve passing through $Q_{0}$ (here, curve $A D$ ). However, if the President, knowing that $Q_{0}$ is regarded as undesirable by the House and Senate, expects a veto to lead to a bill closer to $P$, a veto threat can successfully force the House and Senate to propose a policy near $C$. If none of the three participants is in a dominant position, yet none of thein is sufficiently weak to be forced to gain nothing froin the bill, some intermediate point, such as $B_{0}$, will be enacted.

Once a policy is enacted, the agency inust implement it. In so doing, the agency may shift the policy outcome away from the legislative intent (here $B_{0}$ ). Two important observations can be made about the consequences of policy drift. First, as long as the agency stays within the triangle $P H S$, no legislative correction or punishment is possible. Any policy outcoine within the triangle (that is, within the Pareto optimal set) must be preferred by at least one of the three parties to the original agreement to enact $B_{0}$. Hence, because all three actors have a veto, one of the three will not agree to an action that forces the agency back to $B_{0}{ }^{24}$ Second, if the agency causes policy to drift outside the triangle, all three can agree that a correction and punishment are deserved; however, the new policy is not likely to be $B_{0}$. The reason is that the set of feasible pohicies (the half-lens $A C D$ ) is uniquely determined by the exact nature of the status quo. Hence, the agency's implemented policy outcome is not likely to cause the President and the legislature to agree on $B_{0}$ as the correction, unless the agency has specifically attempted to implement the former status quo, $Q_{0}$.

The issue of protectimg against agency noncompliance has three components. First, if political actors are risk averse, all three will prefer greater certainty in policy impleinentation as compared to random noncompliance (that is, noncomphiance that may drift away from the preferred outcome of each of the three). Second, each of the three wants to minimize the chance that one of the other two will influence the agency against its interests. Nonetheless, all have an ex post incentive to spend resources persuading the agency to sway policy their way. This is a negative sum game, so ex ante all three actors regard such expenditures as wasteful. Third, none of the parties wants to let the agency choose which political actor to favor. The power to

24 Note in this situation that the President is in a more powerful position than the Congress. By exercising the power to fire heads of agencies and to issue executive orders, the President can influence pohicy without obtaining the agrecment of the House and Senate. This opportunity for effective ex post response to noncomplying behavior implies that Congress is likely to be more concerned about structure and process than is the President. 
choose is the power to manipulate, lioldup, and extract. Politicians would not willingly subject themselves to such beliavior by the agency.

\section{B. Structural Constraints Placed on an Agency}

The logic of the preceding argument is that the most effective means for achieving policy stability are constraints on the flexibility of agencies, rather than reliance on rewards, punishments, and oversight. If the agreement within each legislative body and among the President and the two houses of Congress can be clearly articulated in terms of policy outcomes, the best solution is legislative specificity: writing into the law precisely what the agency is to achieve, and how it is to do so. If the best policy from the perspective of the winning coalition depends on arcane information or is uncertain because of frequent clianges in the state of knowledge about the problem that the policy is supposed to ameliorate, however, legislative specificity cannot identify the policy outcome that is embodied in the legislation. ${ }^{25}$ This does not mean that the agency necessarily must be free to violate the spirit of the coalitional agreement. An alternative means of achieving the policy outcome that the coalition would have adopted in the absence of uncertanity is to constrain an agency's policies througl its structure and process by enfranclising the constituents of eacli political actormembers of Congress and the President - that is a party to the agreement to enact policy $B_{0}$.

There are two fundamental ways in which an agency's structure and process can influence its policy decisions. First, because policy decisions depend upon what information is available to the agency, structure and process determine the quantity, quality, and completeness of available information and the extent to which policy decisions must be supported by this information. Political primcipals can control the influence of a constituency by using structure and process to affect the dependence of the agency on information the constituency supplies.

One exaniple is the role of agency resources in enfranchising poorly organized constituents. An agency that lias sufficient resources to generate its own information about the consequences of its decisions, available funds to subsidize the participation in its processes of various poorly organized interests, and a relatively lenient standard for judicial review of its actions (for example, arbitrary and capricious), will be far less dependent on highly organized, well-represented interests than an agency that lacks resources and faces a

25 See Masliaw, Prodelegation: Why Admimistrators Should Make Political Decisions, 1 J.L. Econ. \& Org. 81 (1985). 
high standard for upholding its decisions in court. ${ }^{26}$ Similarly, if cause and effect relationships are uncertain, the assignment of the burden of proof (for example, must a product be proven safe before marketing, as is the case with drugs, or proven dangerous to be prevented from being marketed, as with chemicals) will also affect the influence of different constituencies (for example, chemical compamies versus environmentalists), and hence the ultimate policy outcome.

The second way structure and process encourage compliance is by preventing the agency from presenting pohtical principals with a fait accompli and instead forcing it to warn them well in advance of any potentially noncoinplying decision. A common observation about admmistrative procedures is that they cause delay by requiring agencies to follow intricate and often cumbersoine decisionmaking processes. ${ }^{27}$ The courts are undoubtedly a major source of these procedures, reflecting their attempts to protect individual rights of due process. But there is inore to adıninistrative delay than that. Even witliout court-sponsored procedures, Congress and the President typically want administrative procedures because of the political role they play. Indeed, legislation often miposes procedural complexities that go beyond what the courts have required.

As argued above, when an agency presents politicians with a fait accompli, politicians may find it difficult, if not impossible, to respond. Legislation can reverse the agency, but not before a new constituency is mobilized in support of the new policy. Moreover, some members of the coalition giving rise to the original legislation may actually prefer the agency's decision and oppose reversing it. As long as the agency has been careful to choose a policy within the set of Pareto optimal policies, complete reversal is essentially impossible, and only a partial correction is likely even if the new policy is not Pareto optimal.

26 For a more complete development of these ideas, see Noll, The Political Foundations of Regulatory Policy, in Congress: Structure and Policy 462 (1987).

27 The "problem" of delay has been much criticized by various private and government reports. See, e.g., Federal Regulation: Roads to Reform, 1979 A.B.A. Comm'n L. \& Econ. 92 (criticizing "cumbersome" administrative procedures that result in delay); Staff of Senate Comm. on Gov't Affairs, 95tlı Cong., 1st Sess., Delay in the Regulatory Process ix (Comm. Print 1977) (A Committee poll of about one thousand lawyers practicing regularly before eight major commissions showed that "undue delay" was the most frequently cited major problem with federal regulation. The Committee concluded that "[d]elay is a fundamental impediment to the effective functioning of regulatory agencies."); The President's Advisory Council on Executive Org., A New Regulatory Framework: Report on Selected Independent Regulatory Agencies 5 (1971). Interestingly, none of these reports discusses why Congress and the President have persistently iguored recommendations to end delay by streamlining regulatory processes. 
Administrative procedures erect a barrier against an agency carrying out such a fait accomph by forcing the agency to move slowly- and publicly, giving politicians (informed by their constituents) time to act before the status quo is changed. Consider, for example, the requirements of formal rulemaking. ${ }^{28}$ Before it can issue a change in policy, an agency subject to fornal rulemaking must first announce that it is considering a policy change and solicit the views of all relevant parties. ${ }^{29}$ Often, it is required to announce a "provisional" rule and again solicit still more comments. ${ }^{30}$ In addition, fornal rulennaking requires the agency to conduct a trial-type liearing, allowing interested persons to testify and to cross-examine witnesses. ${ }^{31}$ Only then can it impleinent a new policy by issuing the long-sought new rule. Finally, the agency must produce a record setting forth substantial evidence in favor of its finding and reasons for rejecting alternative findings. ${ }^{32}$

These procedures allow politicians to prevent deviations before they occur. ${ }^{33}$ The meinbers of the coalition enacting the policy can adopt a blanket agreement to inhibit all possible deviations while the nature of the deviation is still in doubt and the coalition has not yet formed that miglit support the deviation. Delay gives the old coalition time to mobilize its constituents before the agency undermmes it by enunciating a noncoinplying policy that changes the status quo.

28 Formal rulemaking is required by the Admmistrative Procedure Act (APA) where the agency-enabling legislation requires rules to be made "on the record after an opportunity for an agency hearing." Administrative Procedure Act, § 553, 5 U.S.C. § 553(c) (1982); see, e.g., Food, Drug, and Cosmetic Act, $\S 301,21$ U.S.C. $\$ 371(\mathrm{e})$ (1982) (procedures for formal rulemaking by the Food and Drug Administration (FDA)); see also United States v. Allegheny-Ludlum Steel Corp., 406 U.S. 742, 757 (1972) (ruling that the APA's formal rulemaking provisions, 5 U.S.C. $\$ \$ 556-557$, govern rulemaking proceedings only if the agency's enabling statute, in addition to providing for a hearing, prescribes explicitly that it be "on the record"); United States v. Florida E. Coast Ry., 410 U.S. 224 (1973) (holding that no hearing was required under the language of the Interstate Commerce Act).

29 See 5 U.S.C. § 553(b)-(c) (1982); see, e.g., 21 U.S.C. § 371(e)(1)-(2) (1982) (FDA procedures).

30 See, e.g., 21 U.S.C. $\S 371(e)(2)$.

31 See 5 U.S.C. $\S 556(d)$; see, e.g., 21 U.S.C. $\S 371(e)(3)$.

32 See 5 U.S.C. $\$ \S 556(\mathrm{e}), 557(\mathrm{e}) ;$ see, e.g., 21 U.S.C. $\$ 371(\mathrm{c})(3)$.

33 Moreover, agencies are prevented from mobilizing a new constituency behind a different policy prior to any decision. Because such actions provide clear evidence that the agency was prejudiced and had made its "decision" prior to completing its procedures and weighing all the evidence, they are easily reversed by the courts. Cf. Crowell v. Benson, 285 U.S. 22, 48 (1931) (finding that ex parte investigation and facts not put into evidence will not support an agency order); NLRB v. A. Sartoris \& Co., 140 F.2d 203, 205 (2d Cir. 1944) ("[I]f an administrative agency ignores all the evidence given by one side in a controversy and with studied design gives credence to the testimony of the other side, the findings would be arbitrary and not in accord with the legal requirement."). 
One low cost route to achieving this end is by attaching appropriations riders that prevent agencies from spending money on ongoing cases or investigations that could cause deviations from the status quo. Because appropriations bills encoinpass large collections of specific programs, they facilitate cooperation among pohticians to thwart all deviations even though each meinber might benefit froin some of thein. ${ }^{34}$ If numerous actions preventing deviations are included in the same bill, the overall incentive to stabilize policy and maintain agreeinents can override individual incentives on any one issue.

To summarize, the potential for agency deviations from intended policies that are difficult for politicians to punislı or correct leads thein to devise institutions that limit an agency's ability to deviate. We liave argued that two aspects of structure and process play this role. The first creates a decisional environment that causes the agency to be responsive to the constituency interests tliat were represented in the enacting coalition. The second delays agency policyınaking. Altliough costly to all, delay enables pohiticians to act to prevent deviations while the coalitional agreennent is still the status quo.

There is an important distinction between this view of structure and process and that einphasized in the literature about adininistrative law and orgamizational design. Typically, the normative content of that literature deals witl achieving efficient outcomes within a process that protects the riglits of people wlio are likely to be affected by a policy decision. Obviously, these issues constitute an important part of a rational political leader's problein in constructing an agency for policy implementation. Protecting constitutional rights is necessary to prevent the courts from invalidating policy and, all else equal, greater efficiency means inore deliverable policy output for affected constituents.

The theoretical arguments presented liere provide a tlird piece of the puzzle of agency design. If policies are inherently conflictual, they necessarily will produce winners and losers. An agreement to cliange policy is an agreeinent to favor soine constituencies over otliers. Hence, part of the challenge of agency desigu is for the inembers of the coalition to use structure and process to cause the decisions of the agency to be inore responsive to the constituencies that the policy is intended to favor and to inaintain the pohitical compromises negotiated at the time of enactment. Specifically, we would expect agency design to exhibit three cliaracteristics.

34 For examples of the use of appropriations riders and informal controls through appropriations hearings, see W. Cary, Politics and the Regulatory Agencies 35 (1967); M. Kirst, Government Without Passing Laws 64 (1969); Weingast \& Moran, Bureaucratic Discretion or Congressional Control? Regulatory Policymaking by the Federal Trade Commission, 91 J. Pol. Econ. 765, 775 (1983). 
First, the agency's structure and process should create a political environment that mirrors the politics at the time of enactment; that is, imterests that are active participants in the debate over the original legislation should be given representation through the structure and process of the agency so that each will be protected against undesirable policy drift. Specifically, the enabling legislation should seek to combine sanctions with an institutional structure to create pressures on agencies that replicate the political pressures applied when the relevant legislation was enacted. Here, the point of administrative procedures is not to pre-select specific policy outcomes but to create a decisionmaking environment that mirrors the pohitical circumstances that gave rise to the establishment of the policy. Although pohitical officials may not know what specific policy outcome they will want in the future, they will know which interests ought to influence a decision and what distributive outcomes will be consistent with the original coalitional arrangement.

Second, the structure and process of an agency should stack the deck in favor of the groups who, among those significantly affected by the policy, are also favored constituents of the coalition that caused the policy to be adopted. And third, agency policies should exhibit an autopilot characteristic in the sense that as the preferences of the constituencies enfranchised in the agency's structure and procedure change, so too will the agency, freeing Congress and the President from having to enact new legislation to achieve that end.

The implication of this is not that policy is necessarily stable, but that it will change only to the extent that either the preferences of the agency's enfranchised constituencies change or a constituency simply withers away and no longer takes advantage of its structural and procedural advantages. In either case, the agency's political overseers are not likely to care about a drift im policy. Because their preferences reflect the preferences of their constituencies, the disappearance of a constituency or a change in its policy desires will make the old policy obsolete in any case. Thus, the problem of noncompliance is not that pohicy drifts, but that it drifts in ways that are harmful to the constituents of a member of the coalition that enacted the policy.

\section{Noncompliance and the Courts}

The federal courts, as well as agencies, can be a source of noncomplying policy outcomes. Vague legislative mandates and weak standards for judicial review give courts an opportumity to shape policy as they see fit. Hence, political actors face a similar problem in trying to limit judicial decisions to the intent of the political coalition that gave rise to the policy.

Although we have not developed a comprehensive theory of pohtical control of the policies promulgated through judicial review, some elements of 
the theory pertaining to agencies also apply to the judiciary. Most importantly, ex post reestabhishment of a coalitional agreement, after a judicial opimon has upset the status quo, is likely to be difficult. ${ }^{35}$ Like an agency, a court is safe from legislative reversal as long as its new pohicy is within the Pareto optimal set established by the preferences of the House, the Senate, and the President. As with agencies, one potential means of protecting against judicial readjustment of policy is to use either explicit legislation or administrative procedures in an attempt to constrain judicial decisions. The problematic aspect, however, is precisely how judicial opinions can be constrained, especially those rendered by the United States Supreme Court, where the only check upon nakedly noncomplying policymaking is legislative correction. Unlike agencies, or even lower courts, the Supreme Court lacks an external standard for its own decisions other than legislative response. This suggests that elected political officials are likely to be less effective with the Supreme Court than with agencies in using ex ante constraints to prevent direct contravention of their policy preferences.

\section{Regulating Air Pollution}

The history of federal air pollution legislation provides a natural experiment for illustrating and testing the ideas of Part I of this Article. Since 1955, the methods of regulating air pollution have changed many times, including four times during the decade from 1961 through $1970 .{ }^{36}$ Importantly for our purposes, much of this revision consisted of changes in the structure and process through which policies were developed and enforced. Moreover, many of the policy changes in the 1970 s followed court decisions that were, arguably, unanticipated by members of the policymaking branches. Thus, these changes exemplify the type of policy drift, as in Figure 2 , that is likely to be uncorrectable by members of the legislative coalition.

In this Part we conclude that the policy choice made by the enacting legislative coahition in the 1970 Amendments was unrecoverable after the courts intervened by requiring prevention of significant deterioration (PSD), and that because of the structure of preferences, the courts' policy could not be substantially amended by the policyınaking branches. What remained for inembers of the policymaking branches, then, was to reform the structure and process of EPA decisionmaking to protect themselves from further

35 Marks's recent work studies in detail the problem of judicial review of legislation, focusing on the conditions when politicians can reinstate and judicial change in policy. See B. Marks, A Model of Judicial Infiuence on Congressional Policyınaking: Grove City College v. Bell (Nov. 1988) (Hoover Institution Working Papers in Political Science P-88-7).

36 See infra notes $40-54$ and accompanying text. 
seemingly random policy shocks. We examine some aspects of these reforms in Part III of this Article.

The argument we make for the above conclusion takes four steps. First, in order to identify the underlying dimensions of the policy choice, we explore the early evolution of federal air pollution regulation. This exploration also allows us to identify the status quo pohicy as of the passage of the 1970 Amendments. Second, we argue that the courts' imterpretation and the subsequent EPA promulgation constituted an unanticipated policy change. Third, we identify the preferences of the inembers of each policymaking branch and show how their preferences shaped their response to the court's intervention. And fourth, we describe the nature of the new policy equilibrium.

\section{A. First Step: The Evolution of Federal Clean Air Policy}

Two abiding policy issues have been at center stage in the history of air pollution regulation: federalism and the tradeoff between strimgency and economic development (that is, what level of pollution will be tolerated and who will bear the costs-established industries and areas or new industries and undeveloped areas). The federalism question pertains to the appropriate division of responsibilities among federal, state, and local authorities. The core of the economic tradeoff is that, generally speaking, economic development goes hand-im-hand with increased air pollution. Hence, if polluted areas are to be made cleaner, the cost is some reduction in economic activity, and if pristine areas are to remain clean, the cost is a sacrifice of some economic growth.

Between 1955 and 1970, both issues were slowly being resolved. The responsibility for air pollution control slowly migrated to the federal government, reflecting a gradual evolution of the views of state and local government officials. The latter, though by no means unanimously or unambiguously favoring an expanded federal role, caine to understand two primary difficulties in relying on decentralized (that is, state as opposed to federal) regulation. The first was the presence of informational economies of scale. Key aspects of environmental regulation involve assessing the dainages caused by pollution, the relationship between emissions and air quality, and the costs of abatement. Not only is the current state of knowledge on these issues complex and voluminous, it is also evolving rapidly. Hence, a regulator faces a formidable task in developing and maintaining a reasonably complete knowledge base for infornning regulatory decisions. Federalization centralizes this responsibility and avoids duphicating essentially the same infornational activities in numerous jurisdictions. Indeed, the first federal legislation in this area, the 1955 Air Pollution Control Act, dealt exclusively 
with this problem. ${ }^{37}$

The second difficulty arising from decentralized regulation was the possibility that localities would compete for industries by offering more relaxed regulation. The problem with decentralized air pollution regulation can be regarded as a "prisoner's dilemma" in the following sense. All localities may prefer clean air, and if all localities simultaneously enact rigorous standards few industries will have any incentive to relocate. But the commumity that acts first may impose such sufficiently high costs on its local industries that they close their facilities, either moving elsewhere or being displaced by companies located in communities that have not yet acted. ${ }^{38}$ The two key features of this problem are the difficulties of coordinated action and the necessity of overcoming the incentive facing each community to be a hittle more lax than the others in regulating its industries to give itself a competitive edge. Federalization of regulation attacks these problems. A federal regulator can impose regulations simultaneously on all communities and can inflict punishments on communities that do not make reasonable efforts to enforce these standards. ${ }^{39}$

The first step in federalizing regulatory authority was a modest one-the Clean Air Act of 1963 authorized the Secretary of HEW to take legal actions in a very himited range of circumstances. ${ }^{40} \mathrm{~A}$ more significant step was taken in 1965, when HEW was given the authority to establish national emissions standards for automobiles. ${ }^{41}$ This was only a partial assertion of federal jurisdiction because the national standards were to be a minimum-

37 The 1955 Air Pollution Control Act authorized HEW and the Public Health Service to conduct and sponsor scientific studies of air pollution and to coordinate information collection to assist state and local authorities in controlling air pollution. See Air Pollution Control Act, ch. $360, \S 1,69$ Stat. 322, 322 (1955) (codified as amended at 42 U.S.C. $\$ 7401$ (1982)).

38 The argument about industry relocation is developed in Pashigian, Environmental Regulation: Whose Self-Interests are Being Protected?, 23 Econ. Inquiry 551 (1985). Pashigian shows that the political problem is even more complicated if not all localities or regions want the same level of pollution control (e.g., if growing regions such as the Southwest are willing to sacrifice control for growth while slow-growing or stagnant areas prefer strong controls). Id. at 552-54.

39 To achieve this, of course, requires giving federal officials coercive powers either over officials at other levels of government who are responsible for regulating air pollution or directly over the sources of pollution.

40 The Secretary was authorized to take administrative or legal actions to deal with air pollution that posed a significant threat to human health if state and local actions proved ineffective, if the problem involved interstate pollution (after consultation with state officials), or if the Governor of the affected state or a state air pollution agency requested help from the Secretary. Clean Air Act, Pub. L. No. 88-206, § 5(c), 77 Stat. 392, 396 (1963) (codified as amended at 42 U.S.C. $\$ 7401$ (1982)).

41 See Motor Vehicle Air Pollution Control Act, Pub. L. No. 89-272, § 202(a), 79 Stat. 992, 992-93 (1965) (codified as amended at 42 U.S.C. § 7521 (1982)). 
they did not displace any more stringent standards that might be adopted by a state.

Shortly thereafter, the issue of nearly complete assertion of federal authority was raised by President Lyndon Johnson, who in 1967 proposed that HEW be given the authority to set national uniform emissions standards for specific pollutants. ${ }^{42}$ Congress did not go as far as the President proposed, but it did further federalize regulation im two ways. First, it preempted state regulation of automobile emissions in all states except Califormia. ${ }^{43}$ Second, it authorized HEW to regulate air pollution in any locality when a state had failed to do so and when pollution in the area posed a threat to public health. ${ }^{44}$

The 1970 Amendments further reallocated responsibilities to the federal government. ${ }^{45}$ By 1970 , state and local government officials generally subscribed to the view that centralized responsibility for setting air quality standards was desirable. ${ }^{46}$ This was largely a response on the part of state governments to their own failure to tackle the pohtical issues imvolved.

The expanding role of the federal government brought to the fore the issues of stringency and cost. The 1970 Amendinents authorized the newly created Environmental Protection Agency to set uniform national ambient air quality standards and emissions standards for new stationary sources of pollutants. ${ }^{47}$ They also authorized the EPA to set emissions standards for both new and old sources of hazardous air pollutants. ${ }^{48}$ The 1970 Amendments required states to adopt plans that would enable them to implement the EPA's requirements and authorized the EPA to impose a plan on a state that did not develop an adequate plan on its own. ${ }^{49}$ The EPA was further empowered to take legal action against violators of its standards, leading to fines and/or imprisonment. ${ }^{50}$ The 1970 Amendinents defined new source

42 See 23 Cong. Q. Almanac 875 (1967).

43 See Air Quality Act of 1967, Pub. L. No. 90-148, § 2, 81 Stat. 485, 501 (codified as amended at 42 U.S.C. $\$ 7543$ (1982)); see also 23 Cong. Q. Almanac 875 (1967) ("The [Act] provided that automobile exhaust standards could be issued only by the Federal Government, except for Califorma, which was permitted to enforce its own (and more stringent) control standards. No other state was given this authority.").

44 Air Quality Act of 1967, Pub. L. No. 90-148, § 2, 81 Stat. 485, $491-97$ (codified as amended at 42 U.S.C. $\S 7415$ (1982)).

45 See Clean Air Amendments of 1970, Pub. L. No. 91-604, $\S 107-116,84$ Stat. 1676, 167889 (codified as amended at 42 U.S.C. $\$ \S 7407-7416(1982)$ ).

46 See 28 Cong. Q. Weekly Rep. 973 (1970).

47 Clean Air Amendments of 1970, Pub. L. No. 91-604, $\S \S 109,111,84$ Stat. 1676, 1679-80, $1683-84$ (codified as amended at 42 U.S.C. $\$ \$ 7409,7411$ (1982)).

48 Id. $\S 112,84$ Stat. at $1685-86$ (codified as amended at 42 U.S.C. $\S 7412$ ).

49 Id. $\S \S 110,113,84$ Stat. at $1680-83,1686-87$ (codified as amended at 42 U.S.C. $\$ \S 7410$, 7413).

50 Id. $\S 113,84$ Stat. at $1686-87$ (codified as amended at 42 U.S.C. $\S 7413$ ). 
performance standards (NSPS) in terms of the technology required, not in terms of emission levels. ${ }^{51}$ They defined NSPS as a "standard for emission of air pollutants which reflects the degree of emissions limitation achievable through the application of the best system of emission reduction which (taking into account the cost of achieving such reduction) the [EPA] Administrator determines has been adequately deinonstrated." 52

Finally, the EPA was given the authority to regulate the composition of fuels for inobile sources of pollutants if the fuels posed a threat to public liealtli or damaged pollution control devices. ${ }^{53}$ What reinained for state and local authorities was to write emissions standards for existing stationary sources that achieved national air quality requirements and to enforce these standards and the standards for new sources proinulgated by the EPA. ${ }^{54}$

The slow evolution of federal regulation of air quality reflected the underlying politics of the period. First, the growing constituency for environmental policy put ever-increasing pressure on all levels of government to inake progress in cleaning the air. Second, improving the air required miposing costs on sources of pollution. Moreover, because significant improvements required that firms develop new technologies for abatement, in soine cases industry faced a fixed development cost that was unlikely to affect its production costs and, therefore, was unlikely to be coinpletely recovered later in price increases or productivity advancements. Hence, significantly more stringent environmental regulation was regarded as an unrecoverable wealth transfer away from the owners and einployees of affected industries. And if the regulations were inposed discontinuously -in the form of a one-tine substantial cost shock-some firms could be bankrupted and soine facilities closed. Needless to say, political officials would be wary of imposing such shocks on their constituents. Thus, the problem in designing an institution for proinulgating air pollution control policies was to inake progress on the air quality front while not disrupting local economies.

Because the policy problein was slirouded in uncertainty concerming the costs of pollution and its abatement-including the amount of abateinent that was teclinologically feasible-the regulatory process would benefit from flexibility in responding to new information. But with flexibility connes the possibility of noncomplying beliavior by either of two sets of regulators: the federal officials proinulgating national standards or the state and local offi-

51 Id. $\S 111(a)(1), 84$ Stat. at 1683 (codified as amended at 42 U.S.C. $\S 7411(a)(1)$ ).

52 Id.

53 Id. $\$ 211$ (c)(1), 84 Stat. at 1698-99 (codified as amended at 42 U.S.C. $\$ 7545(c)(1)$ ).

54 Id. $\$ 110,84$ Stat. at 1680-83 (codified as amended at 42 U.S.C. $\$ 7410$ ); see also H.R. Conf. Rep. No. 1783, 91st Cong., 2d Sess. 45, reprinted in 1970 U.S. Code Cong. \& Admin. News 5374, 5377-78 (report accompanying H.R. 17,255 describing the states' role in the adoption and enforcement of implementation plans). 
cials making and enforcing implementation plans. Hence, capturing the benefits of flexibility while minimizing the risk of noncomphance required the development of a process that would prevent both a drift away from progress toward cleaner air and disruption of local economies.

\section{B. Second Step: Policy Innovation by the Courts and the Evolution of PSD}

Soon after the passage of the 1970 Amendments, the EPA promulgated regulations regarding degradation of air quahty in areas with clean air. ${ }^{55}$ The EPA concluded that the intent of Congress was for the agency to establish a umiform nationwide air quality standard that would not require a strict rule against degradation of air quality in pristine regions. ${ }^{56}$ The Sierra Club appealed this decision to the Umited States District Court for the District of Columbia, which eventually ruled that the EPA had to reject state implementation plans (SIPs) that did not prevent the degradation of air quality in clean air regions. ${ }^{57}$ The ruling caused the EPA to reinstate the nondegradation policies it had previously discarded. Because of the ruling, the EPA replaced the uniform national ambient air quality standards it had proinulgated pursuant to the 1970 Amendments with a multiplicity of standards based not on health or welfare considerations but on each region's actual air quality. ${ }^{58}$

The legislative history of the 1970 Amendments provides scant basis for beheving that Congress intended the EPA to proinulgate rules to prevent significant deterioration. Judge Pratt of the District of Columbia District Court based his Sierra Club ruling on five items in the legislative history of the 1970 Amendments, ${ }^{59}$ of which only two were actually legislative in origin, and of these two only one actually preceded the 1970 Amendinents. ${ }^{60}$ In his decision, Judge Pratt referred to a sentence in the 1970 report of the Senate Committee on Environınent and Public Works (Senate Public Works Committee) stating that the EPA should disapprove SIPs for clean air areas that did not "provide, to the maximuin extent practicable, for the continued

55 See National Primary and Secondary Ambient Air Quality Standards, 40 C.F.R. $§ 50$ (1972); Requirements for Preparation, Adoption, and Submittal of Implementation Plans, 40 C.F.R. § 51 .

56 These views were encapsulated in a regulation promulgated by the EPA in the wake of the 1970 Amendments requiring only that states not allow air degradation to rise above applicable secondary standards. See 40 C.F.R. $\$$ 51.12(b).

57 Sierra Club v. Ruckelshaus, 344 F. Supp. 253 (D.D.C. 1972), aff'd per curiam by an equally divided Court sub nom. Fri v. Sierra Club, 412 U.S. 541 (1973).

58 R. Melnick, supra note 11 , at 71 .

59344 F. Supp. at 255.

60 For an excellent discussion of the legislative lnistory relied on in the Sierra Club litigation, see R. Melnick, supra note 11 , at 76-80. 
maintenance of such ambient air quality."61 This language could be interpreted as implying PSD, but the report went on to state:

Once such national goals are established, deterioration of air quality should not be permitted except under circumstances where there is no available alternative. Given the various alternative ineans of preventing and controlling air pollution-including the use of the best available control technology, industrial processes, and operating practices-and care in the selection of sites for new sources, land use planning and traffic controls-deterioration need not occur. ${ }^{62}$

A more reasonable interpretation of this passage is that the Senate Public Works Committee did not intend to prevent degradation of clean air areas, but rather intended to require polluters to use the "best available control technology" (BACT). ${ }^{63}$ This interpretation would also be consistent with other discussions of the 1970 Amendments in the report.

Had Congress intended a nondegradation policy, one would expect that the legislative response to Sierra Club would have been a relatively noncontroversial one, featuring at best a few perfecting changes in legislation or some discussions of the details in oversight hearings. Instead, the debate about PSD continued for five years before a very detailed set of PSD rules was finally enacted as a compromise between very different bills passed by the House and Senate. ${ }^{64}$ It is thus reasonable to conclude that the court's decision was a policy innovation that was unanticipated by the policymaking branches.

\section{Implementation of PSD}

In the absence of strict guidelines froin either the court ${ }^{65}$ or Congress, the EPA responded to the ruling in Sierra Club by promulgating regulations to

61 Sierra Club, 344 F. Supp. at 255 (quoting S. Rep. No. 1196, 91st Cong., 2d Sess. 2 (1970)).

62 S. Rep. No. 1196, 91st Cong., 2d Sess. 11 (1970) (emphasis added).

63 For example, the Senate bill proposed that new stationary sources be "designed, built, equipped, operated, and maintained so as to reduce emissions to a mimimum." The performance standards were to be met through the "application of the latest available emission control technology or through other means of preventing or controlling air pollution." Id. at 15-16.

64 See Clean Air Act Amendments of 1977, Pub. L. No. 95-95, $\S \S 160-178,91$ Stat. 685, 731-51 (codified at 42 U.S.C. $\$ \$ 7470-7508$ (1982)). Compare S. 252, 95th Cong., 1st Sess., 123 Cong. Rec. 18,517 (1977) with H.R. 6161, 95th Cong., 1st Sess., 123 Cong. Rec. 16,966 (1977).

65 Indeed, as Melnick points out, the court failed to define what constitutes "significant" deterioration. See R. Melnick, supra note 11, at 77. 
prevent significant deterioration. ${ }^{66}$ These regnlations incorporated three basic features.

First, the EPA defined significant deterioration and established guidelines for the development and submittal of SIPs witli respect to PSD. In no mstance did the proposed rules define significant deterioration in terms other than concentrations of sulfur dioxide and particulate matter. ${ }^{67}$ Further, the determination of what actually constituted significant deterioration was left to the states under this promulgation, with the EPA Administrator retaining the authority to assess whether they conformed to the federal standard. ${ }^{68}$

Second, the EPA provided for the designation of air quality areas under three classifications: class I applied to "areas in which practically any cliange in air quality would be considered significant"; class II applied to "areas im which deterioration normally accompanying moderate well-controlled growtll would be considered insignificant"; and class III apphed to "areas in which deterioration up to the national [ambient air quality] standards would be considered insignificant." ${ }^{\text {"69 }}$ The proposed regulations specified the allowable mcrements in pollutant concentrations over baseline air quality concentrations for class I and class II regions. Areas designated as class III were limited to concentrations of particulate matter and sulfur dioxide no greater than the national ambient air quality standards. ${ }^{70}$ The deterioration increments in class I and II areas were established by emissions ceilings that could not be exceeded by any new major source. The determination of allowable air quality mcrements permitted reductions of emissions froin existing sources to be taken into account in determining the unused portion of the allowable air quality increment. ${ }^{71}$ States could reclassify areas, subject to EPA review and approval, to allow for the introduction of sources not otherwise compatible with the mitial classification if the resultimg deterioration would not be significant. ${ }^{72}$ EPA approval of proposed redesignations would be based on the record of the state's hearings. ${ }^{73}$

Third, the EPA modified the review procedures for new polluting sources by adding considerable detail to the NSPS requirements. New sources, wherever located, would be reviewed to determine their impact on air qual-

66 See 40 C.F.R. $\S 52.21$ (1975).

67 Id. $\S 52.21(\mathrm{c})(2)$.

68 Id. $\$ 52.02$.

69 Environmental Protection Agency Approval and Promulgation of Implementation Plans: Prevention of Significant Air Quality Deterioration, 39 Fed. Reg. 30,999, 31,003 (1974) (EPA Administrator's Aug. 15, 1974 introduction to proposed changes to 40 C.F.R. $\S 52.21$ ).

7040 C.F.R. $\S 52.21$ (c)(2)(i)-(ii) (1975).

71 Id. $\S 52.21$ (d)(2)(i)-(ii).

72 Id. $\S 52.21$ (c)(3)(ii).

73 Id. $\S 52.21$ (c)(3)(ii)(d). 
ity. Preconstruction review would be applied to proposed facilities in inineteen specific inajor source categories. ${ }^{74}$ The list of sources subject to review was expanded to include two additional source types: fuel conversion plants and primary lead sinelters. ${ }^{75}$ The regulations furtlier specified that no construction or inodification of new sources could commence unless the EPA Administrator determined tliat tle effect on air quality would not lead to a violation of air quality increments. ${ }^{76}$ All new or inodified sources were required to ineet an emissions limit representing tlie level of emissions reduction achieved by the application of BACT. ${ }^{77}$ In determining whether the new source inet tlie BACT requirement, the EPA Admmistrator would consider fuels and raw materials available, the respective costs of the application of new control tecliniques, process clianges, or alternative fuels, and any applicable state and local emissions limitations. ${ }^{78}$

A source tliat was inodified but did not increase pollution other than sulfur oxides or particulate inatter, or was inodified to utilize an alternative fuel, was not subject to the new regulations. This provision exempted inodifications of sucl sources as coal cleaning plants, pulp mills; ceinent plants, primary zinc sineiters, iron and steel mills, primary alummum ore reduction plants, and primary copper sinelters from the requirements of the regulation. ${ }^{79}$ As a general rule, thougli, the EPA disapproved SIPs that did not prevent "significant deterioration of air quality in any portion of any State where the existing air quality is better than the national ambient air quality standards." 80

In effect, the regulations promulgated by the EPA required that air quality not be allowed to deteriorate, even if the air quality of a region greatly exceeded national standards. Except in areas witl especially bad air quality, establislied sources generally were not required to aclieve as great a degree of emissions abateınent as new sources. State miplementation plans for nonattainment areas were required to establislı regulatory strategies for existing sources so tliat an air quality region could achieve national standards. New sources were required to adopt tlie best possible control tecl1nologies. Moreover, in nonattainment areas they were furtlier required to abate otlier existing sources so that tlie net effect of the construction of new

74 Id. $\S 52.21(d)(1)(i)-(x i x)$.

75 Id. $\$ 52.21$ (d)(1)(xvii)-(xviii).

76 Id. $\S 52.21(\mathrm{~d})(2)(\mathrm{i})$.

77 Id. $\$ 52.21$ (d)(2)(ii). In this case, BACT was defined to mean "any emission control device or technique which is capable of limiting emissions to the levels proposed or promulgated." Id. § 52.01(f). Where no standards of performance existed, BACT was to be determined on a case-by-case basis considering six enumerated factors. Id.

78 Id. § 52.01(f)(1), (4), (5):

79 Id. § 52.21(d)(1)(i)-(vii).

80 Id. § 52.21(a). 
sources and abatement of existing sources was an improvement in air quality. In both PSD regions and nonattainment areas, NSPS were required; however, in PSD regions a new source did not necessarily have to abate other sources to achieve zero net emissions. But to escape the zero (or close to zero) net emissions requirement, the owner of the new source had to show that the proposed new facility would not cause a significant deterioration of air quality. ${ }^{81}$

\section{Third Step: The Political Response to the Court}

The court's ruling in Sierra Club, together with the EPA's interpretation of the court's requirements in its promulgated regulations, established a new status quo policy. ${ }^{82}$ Here we explore the logic of the proposition that Congress was blindsided by the court on the PSD issue and examme whether subsequent developments are consistent with this proposition. If PSD was a surprise, its effect was an unanticipated movement from a legislative policy agreement ( $B_{0}$ in figures 1 and 2 ) to some new status quo point. Here the source of the movement was judicial pohcymaking, not agency noncomphance. Implicit in this account is that the EPA was correct when it concluded that it lacked legislative authority to develop PSD rules.

Further, if the court's change in policy is also im the set of Pareto optimal outcomes, no significant changes in this policy can be enacted because each institutional actor holds a veto power over proposed changes in the status quo. Thus, the subsequent legislative enactment of basically the same PSD requirements that emerged from the court and the EPA's subsequent rulennaking provides no evidence that PSD was the original intention of Congress in $1970 .{ }^{83}$

\section{The Preferences of the Players}

To shed further light on the PSD issue requires that we examine the policy preferences of the important actors involved in forging the 1970 Amendments. To do so, we examine not only the specific issue of PSD but also the passage of the 1970 Amendments that were determined by the court to require PSD, and Congress's legislative response im 1976 and 1977 to the adoption of PSD.

81 Id. $\$ 52.21(\mathrm{~d})$.

82 Sierra Club v. Ruckelshaus, 344 F. Supp. 253 (D.D.C. 1972), aff'd per curiam by an equally divided Court sub nom. Fri v. Sierra Club, 412 U.S. 541 (1973); see 40 C.F.R. $\$ 52$ (1975).

83 This conclusion parallels Marks's exploration of what kinds of inferences can be drawn about politicians' preferences and intentions based on their subsequent reactions to judicial changes im policy. See Marks, supra note 35 . 
The incentives of political actors are forged through the electoral connection. ${ }^{84}$ Different politicians confront different reelection probleins, ${ }^{85}$ so their mcentives and actions will be sliaped somewhat differently. Indeed, this was the intent of the Constitutional Convention in creating different electoral systems-different constituencies and different terms of office-for Congressinen, Senators, and the President. By giving the inembers of the policymaking branches somewhat different ties to the people, the founding fathers sought to ensure that the theoretical separation of powers was maintained in practice. ${ }^{86}$

The differences in constituencies and terms of office annong elected officials are likely to cause several types of differences in their concerns about policies. First, all else equal, smaller constituencies generally have less diversity of interest and enterprise. This implies that representatives with sinaller constituencies are more likely to see an issue in terms of a single overriding interest. Thus, House meinbers are more likely to be spokesinen for certain industries or groups than Senators whose constituencies are, witli a few exceptions, larger than those represented by House meinbers from their states. Because Senators face larger constituencies and have inore media attention (and because many of thein aspire to the Presidency), they are more likely to be worried about national goals and the larger picture rather than specific industries. Smaller states are likely to be less diversified, so their Senators are inore likely to be cliampions of a single interest. The President, representing a national constituency, will be the least tied to specific industries, groups, or sectors.

Second, the shorter term for members of the House implies that they will apply a higler discount rate than will the President or Senators when considering the long-term costs and benefits of government policy. Because House ineinbers are essentially continuously standing for reelection, they are more likely to favor prograins that have immediate payoffs and delayed costs.

In order to evaluate the positions of members of the House and Senate and of the President, we need to identify the underlying dinnensions of the PSD

84 This line of argument is now standard in the political science literature on Congress. See, e.g., R. Fenno, Home Style: House Members in Their Districts 171-213 (1978) (suggesting how members of Congress first build, then maintain, a "reliable reelection constituency"); $M$. Fiorina, Congress: Keystone of the Washington Establishment 39 (1977) (asserting that "the primary goal of the typical congressman is reelection"); D. Mayhew, supra note 22, at 5 (1974) (describing United States Congressmen as "single-minded seekers of reelection").

85 They face different districts with different primary and reelection constituencies. Because of this, their relationships with their constituents will differ and the actions they take will be predictably different. See R. Fenno, supra note 84, at 1-29.

86 See The Federalist No. 39, at 254-55 (J. Madison) (C. Van Doren ed. 1945). 
tradeoff. The two dimensions are who is to bear the costs of air pollution regulation and the maguitude of the environmental benefits. This translates into how inuch of the cost is to be imposed on established firms and how much is to be born by new enterprises and undeveloped areas, together with how stringent tlie requirements will be.

The position of the President is most difficult to determine ex post because he was less involved in the legislative process. Because of their national constituency, Presidents are inclined to be inore concerned about economic efficiency and less about protecting specific industries. In the case of air pollution legislation, this suggests that the President will pay less attention to the relocational aspects of environmental regulation, and more to minimizing the costs of achieving a given policy objective.

President Nixon was relatively favorably inclined toward environmental regulation, liaving created the EPA througli a Reorganization $\operatorname{Plan}^{87}$ and having proposed mucli of the ultimate contents of the 1970 Amendments. ${ }^{88}$ Under Nixon, however, the EPA rejected PSD in 1971. No doubt this reflected the President's view, for the EPA decision was not followed by an executive proposal to correct the issue in the Clean Air Act so that PSD rules could be proinulgated. Indeed, the Nixon Administration's response to the court ruling was to propose an amendment to the Clean Air Act eliminating the PSD requirement. ${ }^{89}$ It seems reasonable to conclude that Nixon favored somewliat looser overall environmental regulation than that favored by the median (Democratic) meinber of Congress, but did not favor the elaborate use of air pollution regulation to preserve the existing pattern of industrial development, especially at high cost.

The preferences of relevant House and Senate actors are somewliat easier to discern. The arguments presented in Part I of this Article lead us to begin with an exarnination of the policy preferences of the oversight committees in botli cliambers, for congressional rules of procedure give thiem considerable influence in determining the ultimate legislative outcome. ${ }^{90}$ In the House of

87 Reorg. Plan No. 3 of 1970, 3 C.F.R. 1072 (1970), reprinted in '5 U.S.C. app. at 1132 (1982), and in 84 Stat. 2086-87 (1972).

88 See The President's Message on the Environment, Feb. 10, 1970, 116 Cong. Rec. 32,908.

89 See 39 Fed. Reg. 42,509, 42,510 (1974) ("The Administration has submitted for consideration an amendment to the Act which would eliminate tlie requirement for preventing significant deterioration of air quality.").

90 The influence of committees is standard wisdom in congressional literature. See D. Mayliew, supra note 22, at 85-97. The powers underlying this influence include the following three procedures: (1) the monopoly right, held by the oversight committee, to introduce legislation (i.e., a first-mover advantage); (2) the right of committee members to revise amendments proposed by members not on tlie committee; and (3) the practice of populating conference committees with inembers of the committees that have jurisdiction over the bill. These rules give coinmittees two vetoes over legislative actions-one prior to legislative 
Representatives, jurisdiction over environmental legislation resides in the Committee on Interstate and Foreign Commerce (House Commerce Committee). The responsibilities of this committee include oversight of many regnlatory agencies and the Departinent of Commerce. In both 1970 and 1977 its Chairman was Harley O. Staggers (Democrat, West Virginia). It is hardly surprising, then, that the House has been steadfast in using NSPS for electric utilities to protect the West Virginia coal industry.

The overall meinbership of the House Commerce Committee exhibits two additional features. Historically, it has been rather pro-business, having had oversight responsibilities for the host of regulatory agencies that gave rise to the capture-cartel theory of regulation, ${ }^{91}$ and most of its meinbers have been from industrialized, populous states. Of the thirty-six meinbers in 1970, fourteen were from the industrial Northeast and Midwest and four more were from eastern coal-mining states. In addition, five were from California or Texas, sunbelt states with serious urban air pollution probleins. ${ }^{92} \mathrm{By}$ 1977, the House Commerce Committee was even more unbalanced: twentytwo of its forty-three meinbers were from the industrial Northeast and Midwest, three nore were from eastern coal areas, and nine were from California or Texas. ${ }^{93}$ Thus, approximnately two-thirds in 1970 and three-fourths in 1977 of the oversight committee members could be expected to be deeply concerned about the econoinic dislocation effects of air pollution regulation.

For the entire House, concern for protecting specialized local economies is hikely to be strong. Conversely, long-tern pohicies, with costs now but benefits down the road, are likely to be less popular in the House than in the Senate. Hence, the propensity of the oversight committee to be concerned about established industries, though more targeted on traditional manufacturing than the House as a whole, would likely be broadly consistent with the general inchinations of all House members. From these observations, it is

consideration and one afterwards in conference. These vetoes offer committee members special advantages. For a discussion of the effects of these rules, see Shepsle \& Weingast, The Institutional Foundations of Committee Power, 81 Am. Pol. Sci. Rev. 85 (1987).

91 In contrast to the traditional view that bureaus attempt to serve the general welfare are theories that view bureaus as servants of well-defined interests, either because they were set up to serve specific chents (the cartel theory), or because, through the years, they become vulnerable to being taken over by some special interest (the capture theory). For a survey of capture-cartel theories, see Noll, Government Regulatory Behavior: A Multidisciplinary Survey and Synthesis, in Regulatory Policy and The Social Sciences 9, 24-28 (R. Noll ed. 1985).

92 This was somewhat counterbalanced in 1977 because Senator Malcolm Wallop of Wyoming (a major site of western coal) was on the Public Works Committee's Subcommittee on Environmental Pollution. See 1977 U.S. Code Cong. \& Admin. News lxxxv.

93 See 1970 U.S. Code Cong. \& Admin. News cxiii. 
likely that the idea of PSD was congenial to menbers of the House in both 1970 and 1977.

In the Senate, jurisdiction over environmental pohicy resides in the Senate Public Works Committee. The jurisdiction of this committee is wholly different from that of its House counterpart, for public works is a traditional federal pork barrel. Its primary task is to authorize federal construction projects like rivers, harbors, and reclamation. Because these programs are especially important in less populated states, the meinbership of the Senate Public Works Committee differs froin that of the House Commerce Committee.

In 1970, only four of the fifteen meinbers of the Senate Public Works Committee were from the industrial Northeast and Midwest (counting Senator Thoinas Eagleton of Missouri-a debatable classification), and none were from California or Texas. Its main point of coinmonality with the membership of the House Commerce Committee was eastern coal: three Senators represented eastern coal states, including the Chairman, again froin West Virginia, Jennings Randolph. Among the remainder of the Senate Public Works Committee were members from Maine, New Mexico, Alaska, Kansas, and Oregon, states with at best minor problens witl air pollution from industrial sources; and from Virginia, Florida, and Nortl Carolina, sunbelt states witli some track record of attracting new industry away froin the Nortlieast. ${ }^{94}$ By 1977, meinberslip on the committee had shifted even further away from northeastern influence. Although Randolph was still Chairman, only two of the fifteen members represented eastern coal, and only two meinbers were froin the industrial Nortlieast. Largely rural states had a clear inajority, with nine meinbers from the following states: Maine, Vermont, Alaska, North Dakota, Iowa, Colorado, Idaho, New Mexico, and Wyoming. 95

It is difficult to miagine that a cominittee with this composition would have strongly favored protecting eastern manufacturing industries; only Randolph's position as Chairman inakes it plausible that the Senate Public Works Committee favored protecting eastern coal. ${ }^{96}$ Indeed, its inembership and jurisdiction indicate tliat the committee would have preferred economic developinent in clean air areas rather than a strict PSD policy.

The Senate as a body differs froin tle House in two inportant ways. First, in coinparison witli the House, the Senate overrepresents the sparsely populated states of the Great Plains and the West ${ }^{97}$-the kinds of states that

94 See 1977 U.S. Code Cong. \& Admin. News cxvii.

95 See 1970 U.S. Code Cong. \& Admin. News xc.

96 See 1977 U.S. Code Cong. \& Admin. News lxxxv.

97 Relative to the House, malapportionment in the Senate is extreme. For example, a Senator from California represents over fifty times as many voters as a Senator from Wyoming. 
favor federal development projects and that are the mainstay of the Senate Public Works Committee. Second, in most states, Senators have a more diversified constituency and so are less responsive to the needs of particular industries. In addition, their longer terms politically enable Senators to take a longer view of the benefits and costs of policy actions. On balance, these factors make the Senate somewhat less inclined to stress strmgent regulation of air quality in relatively less polluted areas, and less inchined to worry about possible adverse effects of the regulation on specific plants and industries. To the extent the latter issue was important, the Senate would be less mclined to favor using environmental regulation to keep traditional manufacturing industries in the Northeast.

The imphication of this analysis is that the Senate would not have been likely to liave sought PSD rules im 1970. It is unlikely that members of the upper chamber would have favored a pohicy that sacrificed opportumities for pollution control in nonattainment areas in order to use environmental regulation to slow the relocation of industry. Thus, although the Senate might have been inchined to go along with nationwide NSPS, it would not have been imchined to favor tough PSD rules because it represented a long-term commitment to cleaner air everywhere.

\section{Some Evidence on Preferences}

The conjectured preferences for the two chambers of Congress and the President described above are sufficient to yield a single rank-ordering over the two issues involved in the legislation. With respect to allocating the costs of regulation, the members of the House, on àverage, would be expected to prefer to place more of the burden on new industry. Their Senate counterparts would be less inclined to sacrifice growth for the benefit of established firms, and the President would be even less so mclined. Within each cliamber, eastern and Great Lakes representatives, on average, should prefer to burden new firms to a greater extent than would members froin the West and Southwest.

With respect to strimgency, members of the House, on average, represent more urban (and therefore more polluted) areas and so would be expected to favor more stringent regulations than the average member of the upper cliamber, who in turn is more mchned toward strimgent regulation than the President. This conjecture is somewhat controversial as it has often been assumed that it was the Senate rather than the House of Representatives that sought tougher environmental legislation. The median Senators, however,

See Bureau of the Census, Dep't of Commerce, Statistical Abstract of the United States 252 (1988). 
represent clean air areas. This implies that stringent regulation does them little good and may in fact impede growth im their states.

Before proceeding with our analysis we need to define stringency more carefully. In practice, stringency is a complex concept. One aspect is the number of pollutants regulated, and the criteria for establisling maximum concentrations of each. Here we regard a pohicy as more stringent if it regulates more pollutants or adopts more rigorous criteria for setting ambient air quality standards. In addition, stringency lias both a shortrun and longrun aspect. Because of the costs to estabhished firns, members of the House generally preferred to delay stringent regulation (and thus delay or evade the costs to old plants), whereas Senators were more likely to prefer results sooner rather than later. But the House sought greater longrun stringency. The standards it adopted, though taking a longer time to become effective, would eventually result in cleaner air than those proposed by the Senate. In this sense, we regard the House as favoring inore stringeut standards.

Stringency is deterinined not only by the standards enacted, but also by technical and arcane definitions of the technology required (for example, "best available technology" versus "continuous emissions reduction"). Further, requirements to take into account the costs of proposed regulations, or to consider alternative means of accomplishing an end, affect the ability of the EPA Admimistrator to promulgate stringent regulations, at least in the short run. Provisions allowing for exemptions and waivers also reduce stringency by limiting the applicability of standards. Thus, comparing the proposals offered in each chamber involves an examination of much more than just the substantive definitions of the standards so often discussed in the hiterature.

An examination of the proposals and annendments to the Clean Air Act offered in each chamber in the 1970s confirn these conjectures. The amendments to the Clean Air Act offered in the House in 1970 were contained in H.R. 17,$255 ;^{98}$ the Senate's amendments were presented in S. $4358 .^{99}$ In comparing these two bills, three differences are apparent.

The first major difference pertains to the comparative treatment of old and new sources. The House proposed to protect agamst the relocation of existing plants and would have sheltered existing firms from severe cost burdens. For all practical purposes, the House sought to exempt old sources from regulation, while subjecting new sources to stringent control. ${ }^{100}$ To this end, the House bill required that any new source be desigued and equipped to prevent and control emissions to the fullest extent compatible

98 H.R. 17,255, 91st Cong., 2d Sess., 116 Cong. Rec. 19,224 (1970).

99 S. 4358, 91st Cong., 2d Sess. (1970).

100 H.R. 17,255, 91st Cong., 2d Sess. § 5, 116 Cong. Rec. 19,225 (1970). 
with "the available technology and economic feasibility." 101 In interpreting this condition, the report of the House Commerce Committee stated that the promulgation of federal emissions standards for new sources would "preclude efforts on the part of States to compete with each other in trying to attract new plants and facilities without assuring adequate control of extrahazardous or large-scale emissions therefrom."102 The Senate was less insistent about the technology used and instead defined new source performance standards in terms similar to national ambient air quality standards. ${ }^{103}$ The technology bias of the House, of course, illustrates its members' desire to prevent industrial relocation.

A second difference between the chambers was their treatment of economic considerations in setting standards. For example, the House explicitly required the EPA to consider the costs of proposed pollution control techniques im setting national ambient air quality standards ${ }^{104}$ and NSPS, ${ }^{105}$ whereas the Senate left cost considerations imphicit in setting national standards and deemphasized such considerations in NSPS. ${ }^{106}$ Environmentalists have generally fought the consideration of costs in settimg standards, so this difference forns the basis for the belief that the Senate bill was more stringent.

The Senate and House differed in another way that offset the differences over cost considerations. This third difference pertains to the structure and process of standard-setting. The House proposed to delegate far greater discretion to the EPA than the Senate; the House also proposed a mechanism for more effective, and thus more stringent, regulation than would have emerged under the Senate proposal. Whereas the House proposed to delegate the authority to make almost every decision to the Adininistrator, ${ }^{107}$ the Senate proposed to delegate numerous decisions to others. For example, the Senate sought to delegate authority to grant exemptions for implementation plans to the President ${ }^{108}$ and to the courts. ${ }^{109}$ By creating more veto points, the Senate gave opponents of stringent standards a greater likelihood of both delay and success.

101 Id., 116 Cong. Rec. 19,226.

102 H.R. Rep. No. 1146, 91st Cong., 2d Sess. 3, reprinted in 1970 U.S. Code Cong. \& Admin. News 5356, 5358.

103 S. 4358, 91st Cong., 2d Sess. $§ 6$ (1970).

104 See H.R. 17,255, 91st Cong., 2d Sess. $\S 5,116$ Cong. Rec. 19,225 (1970).

105 Id. § 5, 116 Cong. Rec. 19,225.

106 S. Rep. No. 1196, 91st Cong., 2d Sess. 16 (1970).

107 H.R. 17,255, 91 st Cong., 2d Sess. § 4, 116 Cong. Rec. 19,224 (1970).

108 S. 4358,91 st Cong., $2 d$ Sess. $\S 7$ (1970).

109 Id. $\S 6$. 
The Senate also was inore detailed, and hence inore constraining, in its definition of the Administrator's duties. For example, the Senate proposed that the EPA estabhish air quality standards for three categories of pollu$\operatorname{tants}^{110}$ whereas the House offered no such restriction. Moreover, the House left open the ineans by which new sources were to comply with national standards, calling for the lowest possible emissions given cost efficiency, and thereby giving more flexibility to the Administrator. ${ }^{111}$ The Senate wanted NSPS to be met through the application of the best available emissions control technology. ${ }^{112}$

Finally, the Senate proposed many more ways in which states or sources could exempt themselves from the requirements of the Clean Air Act or waive the implementation of standards, at least teinporarily. The Senate would have allowed state implementation plans to contain less rigorous standards than the national standards for up to three years, ${ }^{113}$ whereas no such escape was allowed in the House bill. The House proposed that the Administrator be permitted some limited discretion to exempt new facilities froin compliance for reasons of public health, research, or national security or, in the case of federal facilities, if determined to be in the "paramount interest of the Umited States." 114 The Senate, however, would have allowed the Administrator to grant extensions, ${ }^{115}$ the President to exempt federal facilities, ${ }^{116}$ and governors to petition the courts for exeinptions. ${ }^{117}$ The Senate would have also allowed waivers if the Secretary found that the source had achieved inaxinum air pollution control using the best available teclinology. ${ }^{118}$ Relief could be obtained from the courts when substantial effort could be shown. ${ }^{119}$

Taken together, the greater burden imposed by the Senate on the Administrator, the more limited authority given the Administrator, and the greater ability for others to grant exemptions and waivers of the standards estab-

110 Id. $\S \S 5$ (including agents covered by air quality criteria that affect public welfare, agents emitted by stationary sources, and agents that "available material evidence indicates are hazardous to the health of persons").

111 H.R. 17,255, 91 st Cong., 2d Sess. $§ 5,116$ Cong. Rec. 19,225 (1970); see H.R. Rep. No. 1146, 91st Cong., 2d Sess. 3, 10, reprinted in 1970 U.S. Code Cong. \& Admin. News 5356, 5358, 5365-66.

112 S. Rep. No. 1196, 91st Cong., 2d Sess. 16.

113 Compare S. 4358, 91st Cong., 2d Sess. $\$ 6$ (1970) with H.R. 17,255, 91st Cong., 2d Sess. $\S 4,116$ Cong. Rec. 19,225 (1970).

\14 H.R. 17,255, 91st Cong., 2d Sess. $\S \S 5,10,116$ Cong. Rec. 19,225, 19,228.

115 S. 4358, 91st Cong., 2d Sess. $§ 6$ (1970).

116 Id. $\S 7$.

117 Id. $\S 6$.

118 Id.; see S. Rep. No. 1196, 91st Cong., 2d Sess. 57-58.

119 S. 4358,91 st Cong., 2d Sess. $§ 6$ (1970). 
lished by the Administrator lead us to conclude that the Senate sought a less stringent air pollution policy. The effect of the Senate provisions was to make it more difficult for the EPA to implement stringent policies effectively. ${ }^{120}$

\section{The Congressional Response to Policy Innovation}

During 1976 and 1977, both the House and the Senate considered numerous responses to the PSD policy that the EPA promulgated in 1974. The actions they ultimately chose reflect the preferences we conjectured on the basis of electoral considerations. The aspects of the House proposals in 1976 and 1977 that provided a measure of protection for existing firms, particularly manufacturing firms in the Northeast and Midwest, are well-documented elsewhere, ${ }^{121}$ and we will not review them here. Our focus is on the differences between the policy preferences of the House and Senate as revealed in the bills each produced in these years. In general the House bills proposed PSD regulations that were more stringent than those the Senate produced.

In 1976, the House and Senate bills offered different definitions of PSD. Both chambers defined PSD in relation to the maximum allowable mcrements of pollution over baseline concentrations for each designated control region, but differed over which pollutants would be subject to PSD requirements and how those requirements would be met. In the House, increments were established for all pollutants for which there existed a national ambient air quality standard. ${ }^{122}$ The EPA was to implement this by requiring standards of performance that reflected "tlie degree of emission reduction achievable througln the application of the best technological system of continuous emission reduction." 123 The Senate, lowever, specified deterioration mcrements only for sulfur oxides and particulates, and recommended that these standards be met through the relatively weaker requirement of the "best available control teclinology." 124 Continuous emissions reduction is a more stringent requirement than BACT in two respects: first, the continuous emissions reduction requirement was meant to forbid intermittent nonattain-

120 Cf. McCubbins, The Legislative Design of Regnlatory Structure, 29 Am. J. Pol. Sci. 721 (1985) (examining the manner in which substantive discretionary authority availablc to an administrative agency is fashioned through the scope of regulatory activities granted to the agency, the instrumentality by which the agency can implement its policy choices, and the procedures required for agency decisionmaking).

121 See B. Ackerman \& W. Hassler, supra note 11, at 29-57.

122 See H.R. 10,498, 94th Cong., 2d Sess. § 108(a), 122 Cong. Rec. 30,780 (1976).

123 Id. $\$ 111,122$ Cong. Rec. 30,784.

124 S. 3219, 94th Cong., 2d Sess. § 6, 122 Cong. Rec. 30,763 (1976). 
ment by sources even for short periods of time; second, it was not restricted to "available" technology.

As in the regulations the EPA promulgated in 1974, the House bill specified three classes of clean air areas subject to PSD. Class I included national parks and wilderness areas, and class II encompassed all other attainment areas. ${ }^{125}$ The states could also designate (or redesiguate) some areas as class III, which were to be clean air areas in which industrial development would be permitted and im which air quality levels would be allowed to deteriorate to the national standard. ${ }^{126}$ But before doing so, the states were required to give notice and to hold public hearings. ${ }^{127}$

The 1976 Senate proposal specified only two classes of attainment areas. Like the House bill, class I included parks and wilderness areas and class II included all remaining areas. ${ }^{128}$ But the Senate bill rejected the policy promulgated by the EPA and accepted by the House that some clean air areas should be set aside for mdustrial development where deterioration to the national standard would be allowed, as im the proposed class III areas in the House bill. The Senate Public Works Committee report stated that the wording of the Senate bill was intended to reject the policy that class I areas should remain pristime. Western Senators with large fractions of their states contained in national parks and wilderness areas continually sought to redefine and weaken the class I definitions. ${ }^{129}$

The House allowed for compliance date extensions im its rules, but the Senate, as in the 1970 Amendinents, allowed for many more exemptions and waivers. ${ }^{130}$ Further, the House imposed somewhat tighter procedural requirements for granting waivers-the EPA Administrator could grant compliance date extensions only with notice and a public hearing "on the record," and the governor of the affected state was given the power to veto such actions. ${ }^{131}$

In its report accompanying the Senate bill, ${ }^{132}$ the Senate Public Works Committee stated that its intent was to restrict the EPA's role in preventing siguificant deterioration. ${ }^{133}$ Its proposal was to limit the EPA's role in

125 H.R. 10,498, 94th Cong., 2d Sess. § 108(a), 122 Cong. Rec. 30,781 (1976).

126 Id.

$127 \mathrm{Id}$.

128 S. 3219, 94th Cong., 2d Sess. § 6, 122 Cong. Rec. 30,763 (1976).

129 S. Rep. No. 717, 94th Cong., 2d Sess. 25 (1976).

130 Compare H.R. 10,498 §§ 103(a), 106(a), 112, 202, 122 Cong. Rec. 30,776, 30,778, $30,785,30,787$ (1976) with S. 3219 §§ 7(a), 9(a), 15, 122 Cong. Rec. 30,764-65, 30,768 (1976).

131 H.R. 10,498 § 103(a), 122 Cong. Rec. 30,776 (1976); sec also H.R. Conf. Rep. No. 1742, 94th Cong., 2d Sess. 90-91 (1970) (discussing the comphance date extension procedures contained in the House bill).

132 S. 3219, 94th Cong., 2d Sess., 122 Cong. Rec. 30,763 (1976).

133 S. Rep. No. 717, 94th Cong., 2d Sess. 2-3 (1976). 
implementing a new PSD pohicy to: (1) approving the new source review estabhished by the state; ${ }^{134}$ (2) seeking injunctive relief or other ineasures necessary to prevent the issuance of a permit for new sources that did not comply witl air quality requirements; ${ }^{135}$ (3) resolving interstate disputes; ${ }^{136}$ and (4) notifying a state when it beheved an adverse impact might occur in a class I area. ${ }^{137}$ In essence, the EPA's role was restricted to assuring compliance with the law. Lastly, the Senate proposed to transfer the autliority to grant exemptions for coal conversion from the EPA to the Federal Energy Admimistration, presumably to reduce the influence of environmental policy on the granting of exemptions while mcreasing the importance of energy policy. ${ }^{138}$

The conference committee appointed in 1976 to reconcile the two bills accepted all of the amendments to the 1970 Clean Air Act that each house offered individually, and compromised on all amendments over which the two houses differed. ${ }^{139}$ The conference accepted the Senate's weaker definition for class I areas, ${ }^{140}$ while also adopting the House proposal to allow the redesignation of areas to class III. ${ }^{141}$ The conference settled on the Senate's plan to implement BACT but accepted many of the House's procedural demands and all of the proposed exemptions of both chambers. Despite these modifications, the bill failed to pass. ${ }^{142}$

In 1977, botli chambers proposed bills similar to their 1976 proposals. The House, however, proposed regulations even more stringent than they had the year before. They added mitrogen dioxide to the hist of pollutants subject to national standards, ${ }^{143}$ added "visibility" as a criterion for setting standards in class $I$ areas, ${ }^{144}$ and placed additional burdens and standards of proof on new sources in meeting compliance requirements. ${ }^{145}$

\footnotetext{
134 Id. at 27.

135 Id.

136 Id.

137 Id.

138 S. 3219, 94th Cong., 2d Sess. § 15(b)(7), 122 Cong. Rec. 30,768 (1976).

139 See H.R. Conf. Rep. No. 1742, 94th Cong., 2d Sess. 85-125; see also 122 Cong. Rec. 34,380-88 (1976) (statement of the bill's floor manager, Senator Edmund Muskie of Maine, summarizing the conference report provisions).

140 See H.R. Conf. Rep. No. 1742, 94th Cong., 2d Sess. 103 (1976).

141 Id.

142 The Senate attempted to take up consideration of the conference report on the final day of the 94th Congress, but did not reach a final vote on the agreement. See 122 Cong. Rec. 34,415-17 (1976).

143 H.R. Rep. No. 294, 95th Cong., 1st Sess. 41, reprinted in 1977 U.S. Code Cong. \& Admin. News 1077, 1119.

144 Id. at 13, reprinted in 1977 U.S. Code Cong. \& Admin. News at 1090-91.

145 Id. at 190, reprinted in 1977 U.S. Code Cong. \& Admin. News at 1268-69.
} 
By contrast, the 1977 Senate proposal sought less stringent requirements than those of their relatively weaker 1976 proposal. For example, the Senate sought to exempt small polluters. ${ }^{146}$ Ultimately, the provisions of the conference report for these sections were much the same as in 1976, and in the end, although both chambers proposed significant changes, the final legislation differed hittle in substantive detail from the original 1974 EPA promulgation.

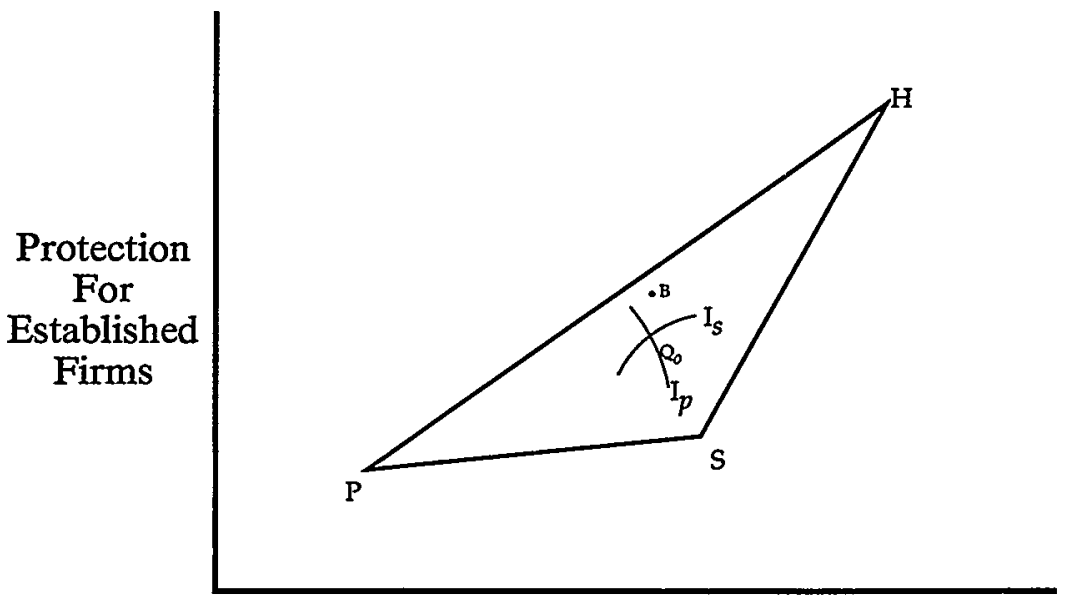

Stringency of Regulation

Figure 3

\section{Fourth Step: The New Equilibrium}

The inference to be drawn from this discussion of the history of the Clean Air Act between 1970 and 1977 is as follows. If the relative positions of the House, Senate, and President are as described, and if the 1970 Amendments were not intended to produce PSD, the 1972 court decision in Sierra Club v. Ruckelshaus ${ }^{147}$ upset a policy equilibrium. The consequences of this unanticipated change $\mathrm{m}$ pohicy can be illustrated by returning to our simple two dimensional model of policy choice. The preferences just established for each institutional actor are illustrated in Figure 3. The House favors greater

146 Compare S. 252, 95th Cong., Ist Sess. $§ 6,123$ Cong. Rec. 18,517 (1977) with S. 3219, 94th Cong., 2d Sess. $\S 6$, I22 Cong. Rec. 30,763 (1976) (providing for a small polluter exemption). Consideration of the Senate bill (S. 252) was indefinitely postponed early in the 95th Congress, and the House bill (H.R. 6161) was passed in lieu of that Senate bill. See Clean Air Act Amendments of 1977, Pub. L. No. 95-95, 91 Stat. 685 (codified as amended at 42 U.S.C. $\$ \S 7401-7642$ (1982 \& Supp. IV 1986)).

147344 F. Supp. 253 (D.D.C. 1972), aff'd per curiam by an equally divided Court sub nom. Fri v. Sierra Club, 412 U.S. 541 (1973). 
stringency than the Senate favors, which in turn favors more stringent regulation than the President. The House, inore than the Senate or the President, prefers that new firms bear the costs of pollution control. The ideal points on the stringency-cost tradeoff among the House, the Senate, and the President are represented in the figure by $H, S$, and $P$.

In Figure 3, the original 1970 policy is represented by point $Q_{0}$. The court decision in Sierra Club and the EPA's promulgated regulation inoved the policy to point $B$. The new policy was in the Pareto optimal set formed by the preferences just identified. There are two implications of this change in pohicy. First, as in our previous analysis, a return to the original pohicy, $Q_{0}$, is not possible. Indeed, the new policy cannot be significantly amended.

Second, the House was the principal beneficiary of the change, for it favored a combination of relatively strict long-terin goals for air quality (which refiected the desires of its urban constituency for cleaner air) and an implementation strategy that would minimally disrupt established economic patterns of development (which reflected its relatively greater sensitivity to narrow industrial interests). PSD strengthened standards in areas that already had clean air. It also slowed progress towards air quality goals by giving greater protection to established industries. A clear implication of EPA's promulgated PSD rules, together with the provisions of the 1970 Amendments regarding new sources, was that existing facilities would be protected against the possibility that stringent air pollution regnlation would hasten their obsolescence. ${ }^{148}$ Consider the requirements for new sources. Generally, it is less expensive to achieve a given degree of pollution abateinent per unit of production in a new facility than in an old one. The reason is that the abateinent system can be included in a new plant's original design, but must be fit into an older plant. Hence, a "least cost" strategy for achieving a given air quality target will often involve replacing older facilities with newer ones. New source performance standards protected existing firms against this eventuality by imposing less demanding requireinents on thein.

This strategy would be far less effective if it applied only to areas with severe air pollution problems. In areas where ennissions could increase significantly without causing air quality to fall short of national standards, new facilities could be built that might face even lower costs of control than those facing established facilities in areas with poor air quality. Nationwide NSPS coinbined with PSD rules inpose on these new facilities a set of regulations almost as demanding as they would face if they located in an area with dirty air. Hence, NSPS and PSD implement the twin policies of improving air quality and protecting established industries against a nationwide redistribution of economic activity due to air pollution regulation. Consequently, the

148 See B. Ackerman \& W. Hassler, supra note 11 , at 10-12. 
court's decision and EPA's subsequent PSD rules moved air pollution policy toward the ideal point of the House.

\section{The Use of Structure and Process to ENForce CONGRESSIONAL INTENT}

The changes in structure and process proposed by eacli chamber in response to the policy innovation of PSD reflect the basic differences in the electoral considerations of the members of each house. These proposed reforms had unambiguous consequences for environmental policy. In this Part we show, first, that the structure and process enacted by Congress for the implementation of air pollution policies by the EPA mirrored the conflict just described between the House and Senate; and second, that the procedures each chamber proposed, and those each eventually adopted, souglit to stack the deck in favor of the interests that chamber represented. As discussed in Part II above, the House proposed procedures to enfranchise local industry, whereas the Senate favored procedures that reduced the force of EPA regulations. In almost every case neither loouse agreed to the changes in PSD proposed by the other, thereby thwarting this avenue of upsetting the status quo.

We examine proposed and enacted changes in the procedures for EPA rulemaking, the standards of proof, and the standards of review of EPA decisions. We then explore proposed changes in the systein of civil representation for the EPA. We describe the debates surrounding the creation of the National Comimission on Air Quality (NCAQ), and show low inembers of eacli cliamber sought to use the NCAQ to alter and constrain the EPA Administrator's ability to implement the new PSD provisions. Lastly, we examine an attempt to enfranchise small independent auto repair shops into EPA rulemaking on auto warranties.

\section{A. Administrative Procedures}

In its proposed 1977 Clean Air Act Ainendments, the House sought to make EPA rulemaking dockets more formal, protracted, and detailed. The House proposed raising the evidentiary standard froin the "arbitrary and capricious" standard of the 1970 Amendments to a "substantial evidence" test in $1977 .{ }^{149}$ In addition, the House proposed a inore restrictive standard under which courts could invalidate EPA rules-namely, that the agency's error had been so "serious and related to inatters of sucl central relevance ... that there is a substantial likelihood that the rule would have been signifcantly changed if such errors had not been inade." 150 The House also speci-

149 H.R. 6161, 95th Cong., 1st Sess. $§ 305$ (a), 123 Cong. Rec. 16,967 (1977).

150 Id. 
fied elaborate rules regardimg the content of rulemaking dockets, and required that more elaborate public hearings and defenses of agency decisions be undertaken. ${ }^{151}$

More elaborate procedures are generally regarded as favorable to regulated industries. Because industries possess mucli of the information relevant to regulatory decisions, elaborate processes give them more power by mcreasing the importance of that information. Anotlier contributing factor is that industries, witl greater economic stakes in regulatory issues, are more likely to devote the resources necessary to be effectively represented in expensive proceedings. In this case, establislied industries (old sources) are more likely to be advantaged by cumbersome proceedings. In the development of NSPS, most of the facilities to whicli these standards would apply do not exist at the time the regulations are promulgated, and for that reason they are less likely to have their interests effectively represented. Indeed, the House hearings indicate that industrial groups representing established industries strongly supported most of the procedural changes that the House Commerce Committee eventually reported. ${ }^{152}$ This is consistent witl the view that the House did not want to disrupt existing patterns of industry through air pollution regulation.

In the Senate, no procedural changes of these types were adopted in 1976 or 1977, and in conference inucl of what the House had proposed was removed. ${ }^{153}$ For example, the recommended "substantial evidence" standard for judicial review was deleted, and the provision requiring cross-exammation of witnesses at public hearings on proposed ruleinaking was replaced

151 See H.R. Conf. Rep. No. 564, 95th Cong., 1st Sess. 177, reprinted in 1977 U.S. Code Cong. \& Admin. News 1502, 1558. For example, the 1977 Amendments contained provisions that specified what documents were to be included in the docket: (1) a statement of the basis and purpose of the rule includimg all data, information, and documents pertiment to the rulemaking procedures; (2) all written comments and documentary information that was of central relevance to the rulemaking; (3) the transcript of any pubhic hearings on the proposed rule; and (4) draft proposals and accompanying documents submitted by the Admimistrator to the Office of Management and Budget, interagency comments on the proposal, and EPA responses to those comments. Clean Air Act Amendments of 1977, Pub. L. No. 95-95, $\S 307(d)(3)-(4)$, 91 Stat. 685, 778-79 (codified at 42 U.S.C. $§ 7617$ (1982)); see also H.R. Rep. No. 294, 95th Cong., 1st Sess. 318-25, reprinted in 1977 U.S. Code Cong. \& Admm. News 1077, 1397-1404 (summarizing House Commerce Committee's reasons for proposed changes in administrative procedures).

152 See Clean Air Act Amendments of 1977: Hearings on H.R. 4151 and H.R. 4758 Before the Subcomm. on Health and Environment of the House Comm. on Interstate and Foreign Commerce, 95th Cong., 1st Sess. 958, 1003, 1044-45 (1977) (statements of Kenneth Tucker, Vice President, Int'l Council of Shopping Centers; Robert Arquila, President, Nat'l Ass'n of Home Builders; and Edward Weber, Ass't Gen'l Counsel, Repubhic Steel Corp.).

153 H.R. Conf. Rep. No. 564, 95th Cong., 1st Sess. 177-78, reprinted in 1977 U.S. Code Cong. \& Admm. News 1502, 1558-59. 
by one that permitted only written rebuttals. ${ }^{154}$ Perhaps most significantly, the Senate refused to accept the House proposal of a one-house legislative veto over EPA rules. ${ }^{155}$ Moreover, although the Senate adopted several House provisions that made EPA's procedures somewhat more elaborate, it insisted that this not affect EPA review of state implementation plans. ${ }^{156}$ Because SIPs are the primary vehicles for regulating existing stationary sources, they contain most of the regulations for established facilities. Preservation of a simple, flexible process for reviewing SIPs meant that specific industries would be less advantaged procedurally in the review of the regulations pertaining to them. To the extent that an industry was advantaged procedurally, it was also advantaged in more general rulemaking, such as the establishment of national ambient air quality standards, NSPS, or emissions standards for mobile sources and hazardous pollutants, all of which affected Senate as well as House constituents.

\section{B. Agency Representation Before the Courts}

Another proposed change involved the relationships between the Department of Justice and the EPA in the latter's representation before federal courts. The 1970 Amendments authorized the Attoruey General to represent the EPA in all cases appearing in federal courts. ${ }^{157}$ Of course, the relationship between the Justice Department and the EPA is not parallel to a normal attorney-client relationship. The Justice Departinent is itself a polcymaking agency, and historically it has been especially closely tied to the President. Thus, when the EPA's staff promulgates a rule that is appealed by an interested party, granting the Attorney General authority to defend the rule creates a de facto veto power that could undermine the defense of the EPA's policy decisions. Of course, one of the most important examples of EPA representation was the Sierra Club case, ${ }^{158}$ in which the Justice Department defended the EPA's decision not to adopt PSD rules.

In 1976, the House Commerce Committee bill ${ }^{159}$ included a provision stripping the Attorney General of his authority to represent the EPA in court, and would instead have authorized the Admimistrator to do so unless

154 Id.

155 Id. at 188-89, reprinted in 1977 U.S. Code Cong. \& Admin. News at 1569.

156 Id. at 177, reprinted in 1977 U.S. Code Cong. \& Adinin. News at 1558.

157 Clean Air Amendinents of 1970, Pub. L. No. 91-604, § 12(a), 84 Stat. 1676, 1707 (1970) (codified as amended at 42 U.S.C. $\$ 7605$ (1982)).

158 Sierra Club v. Ruckelshaus, 344 F. Supp. 253 (D.D.C. 1972), aff'd per curiam by an equally divided Court sub noin. Fri v. Sierra Club, 412 U.S. 541 (1973).

159 H.R. 10,498, 94th Cong., 2d Sess., 122 Cong. Rec. 30,798 (1976). 
he requested that the Attorney General prosecute the case. ${ }^{160}$ On the House floor, Representative M. Caldwell Butler of Virginia proposed an amendment to delete this section of the Committee's bill, statimg that one agency should be responsible for all federal hitigation and that creating a separate litigation staff in the EPA was a "wasteful duplication of resources and efforts."161 Reflecting the power of House rules to protect committee proposals, Committee inember Riclıardson Preyer of Nortlı Carolina immiediately offered a substitute for the Butler amendinent that restored most of what the Committee liad proposed. ${ }^{162}$ Preyer's substitute gave the Justice Department the right to represent the EPA before the Supreme Court and inade the Department a party to decisions about whether the EPA should appeal; lowever, the EPA could represent itself before the courts of appeals (but not the Supreme Court) as long as the Justice Departinent agreed that an appeal could be made. ${ }^{163}$ The House adopted Preyer's substitute to the Butler amendment. ${ }^{164}$ In 1977, when the Committee again reported a bill to amend the Clean Air Act, the Preyer anendment was mcluded in the bill. ${ }^{165}$

The Senate, on the other liand, simply never considered the question of EPA representation in either its 1976 or 1977 bills. In neitler year did the Senate Public Works Coinmittee propose to change the system of representation, and in neither year was such an amendment proposed on the Senate floor. ${ }^{166}$ In the final version of the 1977 Clean Air Act Amendinents (1977 Amendinents), the Justice Department's responsibility to represent the EPA remained, subject, however, to the provisions of a memorandum of understanding between the EPA and the Department of Justice that retained the Departinent's overall supervision, but gave the EPA's lawyers a formal role in developing hitigation strategy. ${ }^{167}$ The 1977 Amendınents state that litigation was to be conducted in accordance with this memorandum of

160 Id. $\S 311,122$ Cong. Rec. 30,798; see also H.R. Rep. No. 1175, 94th Cong., 2d Sess. $272-$ 77 (1976) (discussing the legislative intent of this proposal).

161122 Cong. Rec. 30,499 (1976).

162 Id. at $30,499-500$.

163 Id.

164 Id. at 30,503 .

165 H.R. Rep. No. 294, 95th Cong., 1st Sess. 28, 332-337, reprinted in 1977 U.S. Code Cong. \& Admin. News 1077, 1411-16.

166 Neither conference report contained mention of a Senate proposal regarding EPA representation. See H.R. Conf. Rep. No. 1742, 94th Cong., 2d Sess. 124 (1976); H.R. Conf. Rep. No. 564, 95th Cong., 1st Sess. 173, reprinted in 1977 U.S. Code Cong. \& Admin. News $1502,1554$.

16742 U.S.C. $\$ 7605$ (b) (1982); see also H.R. Conf. Rep. No. 564, 95th Cong., 1st Sess. 17376, reprinted in 1977 U.S. Code Cong. \& Admin. News 1502, 1554-57 (discussing congressional reaction to memorandum of understanding between the EPA and the Department of Justice). 
understanding. ${ }^{168}$

This episode illustrates a number of inportant points. The controversy over representation indicates that all participants regarded the issue as important to the developinent of the details of environinental regulation. Moreover, the House was much more concerned about the Justice Department's pohicy role in environmental matters than were either the Senate or the Administration. In the end, the latter two gave in on one eleinent: the special expertise of the agency demanded that its role in developing cases involving the agency be guaranteed. But the status quo under which the Justice Department supervised litigation whenever the Attorney General (and presumably the President) wanted was not changed. The imphication is that the House had different pohicy objectives than either the Senate or the President-objectives that were threatened by the lack of autonomy at the EPA im representing itself in court.

It is impossible to ascertain precisely what pohicy issues so concerned the House. But one was that the EPA, after initiating the process regarding PSD, first rejected the PSD proposal in accordance with the Justice Department's recommendation, and then had this position vigorously defended by the Justice Department im court. One plausible inference from this sequence of events, as Melnick has previously argued, ${ }^{169}$ is that the EPA imitially wanted to adopt PSD, but decided against doing so after the Administration intervened. If so, the attempt by the House to insulate the EPA from the Justice Department, and the failure of the Senate to comply, is consistent with our hypotheses about the relative pohicy preferences of each. It also supports the view that the strong role given the Justice Department in the 1970 Amendments constituted a procedural protection for the Senate and the President against precisely the kind of drift in agency pohicy that the House preferred-and ultinately obtained froin the courts.

\section{The Use of Studies to Control Agency Rulemaking}

Congress often constrains the ability of an agency to control the flow of information relevant to its rulemaking activities as it did im the 1977 Amendments. This is inost often accomplished by requiring that soine third party conduct an independent study, or in some cases a joint study with the agency, the results of which affect the agency's ruleinaking in some fashion. ${ }^{170}$ These requirements have two effects. First, the third party

168 Clean Air Amendments of 1977, Pub. L. No. 95-95, § 304(a), 91 Stat. 685, 772 (codified at 42 U.S.C. $\S 7605$ (1982)).

169 See generally R. Melmick, supra note 11, at 71-80 (recounting the history of the Sierra Club litigation).

170 See Clean Air Amendments of 1977, Pub. L. No. 95-95, § 403(a), 91 Stat. 685, 792 (codified at 42 U.S.C. $\$ 7548$ (1982)); Toxic Substances Control Act, § 25, 15 U.S.C. § 2624 
enfranchises an important set of constituents interested in the agency's decisions. ${ }^{171}$ Second, the structure establishes a fire alarm oversight systein. ${ }^{172}$ Because the study group has access to all of the information available to the agency, and because their mandate is to inform Congress, the study group is in a perfect position to provide third party oversight for inembers of Congress.

Both aspects of third party studies serve to restrict agency decisionmakmg. Because a study group gives members of congressional committees greater ability to oversee the actions of their agencies, its creation induces agency bureaucrats to comply with congressional wishes. The higher the probability that noncomphant behavior will be discovered, the more effective politicians can be in structuring the agency's imcentives. On occasion, Congress makes this imcentive more direct by fornally linking the agency's decisionmaking to the group's findings. ${ }^{173}$ For example, Congress may require consultation between the agency and a study group, occasionally requiring that a study be conducted jointly by the two. Or it inay require the agency to obtain the study group's agreement on proposed actions. In other instances, Congress may require that the study group's report be part of the agency's proccedings, thereby forcing the agency to respond to the report in its decisionmaking. This also constrains the agency, for the report can then be used as evidence against the agency in court.

For example, the EPA was authorized to undertake several studies in the 1977 Amendments. ${ }^{174}$ Congress also chose to delegate some studies jomtly to the EPA and other agencies and in some instances to bypass the EPA and

(1982) (authorizing a study on establishing a standard classification system of chemicals and related substances and a standard storage and access system for retrieving the information).

171 For example, with respect to establishing air quality criteria, Congress provided that the Administrator of the EPA may "establish a standing consulting committee for each air pollutant ... which shall be comprised of technically qualified individuals representative of State and local governments, industry, and the academic community." 42 U.S.C. § 7408(b)(2) (1982). Congress also required the EPA to utilize third parties in promulgating a national primary air quality standard for mitrous oxides. To assist the EPA, the 1977 Amendments provided for a seven-member independent scientific review committee composed of "at least one member of the National Academy of Sciences, one physician, and one person representing State air pollution control agencies." Congress mandated that the committee "shall complete a review of the criteria published under section 7408 [of Title 42] ... and shall recommend to the Administrator any new national ambient air quality standards and revisions . . . as may be appropriate." Id. § 7409(d).

172 See supra note 15 and accompanying text.

173 See, e.g., Clean Air Amendments of 1977, Pub. L. No. 95-95, § 403(f), 91 Stat. 685, 793 (codified at 42 U.S.C. $\$ 7548$ (1982)) (authorizing the EPA and the National Academy of Sciences to study the effects of emissions on the "public hcalth and welfare" and the technological feasibility of meeting emissions standards).

174 Id. $\$ \S 403-405,91$ Stat. at $792-95$ (codified at scattered sections of 42 U.S.C.). 
to rely completely on a third agency to undertake studies for the EPA and Congress. For example, Congressmen concerned about the effect a ban on aerosols would have on the cosmetics and household products industries required the Secretary of Labor to study the effects of a ban on the use of halocarbons in aerosol containers. ${ }^{175}$ On the same topic, the Administrator was required to establish a coordinating committee for regulating halocarbons. Congress required that the committee include the National Oceanographic and Atmospheric Admimistration (NOAA), the National Aeronautic and Space Administration (NASA), the Federal Aviation Administration, the Department of Agriculture, the National Cancer Institute, the National Institute of Environmental Health Sciences, the National Science Foundation (NSF), and the Department of State. ${ }^{176}$ This coordinating committee was to report to "the appropriate committees of the House and the Senate," not to the EPA. ${ }^{177}$ NOAA, NASA, NSF, the Department of Agriculture, and HEW each were also delegated responsibilities to undertake contmuing studies on ozone and halocarbons. ${ }^{178}$ The National Academy of Sciences (NAS) was asked to conduct three separate studies. ${ }^{179}$

In other instances, Congress has required the EPA to consider a study group's findings. For example, the EPA was ordered to include a statement of a rule's basis and purpose in any notice of proposed rulemaking. ${ }^{180} \mathrm{Con}-$ gress added a requirement to the 1977 Amendments that such statements

shall also set forth or summarize and provide a reference to any pertinent findings, recommendations, and comments by the Scientific Review Coinmittee established under section 7409(d) of this title [42] and the National Academy of Sciences, and, if the proposal differs in any important respects from any of these recommendations, an explanation of the reasons for such differences. All data, information, and documents referred to im this paragraph on which the proposed rule relies shall be included in the docket on the date of publication of the proposed rule. ${ }^{181}$

17542 U.S.C. $\$ 7453(\mathrm{e})(1982)$.

176 Id. $\$ 7453(\mathrm{f})$.

177 Id. $\$ 7453(\mathrm{~g})$.

178 Id. $\S 7454$.

179 Clean Air Amendments of 1977, Pub. L. No. 95-95, §§ 106(a), 403(a), 405(a), 91 Stat. $685,691,792-93$ (codified at scattered sections of 42 U.S.C.).

180 Id. $\S 305($ a), 91 Stat. at 774 (codified at 42 U.S.C. $\$ 7607$ (1982)).

18142 U.S.C. $\$ 7607$ (d)(3) (1982). 


\section{The National Commission on Air Quality}

The use of studies to enfranchise the interests of each party to an enacting coalition, to create a more effective fire alarm oversight system, and to mirror the policy conflicts at the time of legislative enactment are exemplified in the debate surrounding the creation of the National Commission on Air Quality. This debate illustrates the strategic use of structure and process to constrain agency decisions.

The Senate proposed to make the "achievement and maintenance of national ainbient air quality standards" and "prevention of significant deterioration" the NCAQ's principal areas of investigation. ${ }^{182}$ Secondarily, the Senate would have authorized the NCAQ to examine unregulated pollutants and to address the adequacy of abatement research and development and the ability of federal, local, and state agencies to implement the purposes of the Clean Air Act. ${ }^{183}$

The 1976 Senate bill proposed a sixteen-member NCAQ comprised of twelve members of the public (including four governors), to be appointed by the President with the advice and consent of the Senate, and four nonvotimg Congressmen. The four governors or their appointed representatives would have provided state imput into the congressional advisory reports. In effect, the NCAQ would have provided a means for the states to check EPA actions. It would also have been required to seek consultation from federal, state, and local agencies. To facilitate congressional oversight, the chairman and ranking minority member of both the Senate Public Works Committee and the House Commerce Committee would have been nonvoting ex officio members. ${ }^{184}$

The 1976 House amendment to the Senate bill would have established a similarly structured NCAQ composed of eleven members, including the chairman and ranking minority member of the Senate Public Works Cominittee and the House Cominerce Committee. ${ }^{185}$ The House conference committee report reflected many of the same concerns as the Senate committee report, except that this version reflected a greater concern with the effect of EPA regulations on the automobile industry. The final version of the bill required the NCAQ to focus its studies on the "extent to which the reduction of hydrocarbon emissions is an adequate or appropriate method to achieve primary standards for photochemical oxidants"186 as well as the means of achieving and maintaining "national ainbient air quality standards

182 S. 3219, 94th Cong., 2d Sess., § 38, 122 Cong. Rec. 30,773 (1976).

183 Id.

184 Id.

185 Id. $\S 108(f), 122$ Cong. Rec. 30,783 (House amendment to Senate bill).

186 H.R. Conf. Rep. No. 1742, 94th Cong., 2d Sess. 76 (1976). 
and ... the prevention of significant deterioration of air quality," 187 the Senate's primary concern.

The strategic use of structure and process - $m$ this case the requirement of a study - to constrain agency decisions is exemplified by the attempts im both chambers to ainend the provisions creating the NCAQ. In the 1976 Senate debate, the central area of controversy was the relationship between the proposed NCAQ study to the implementation of PSD requirements as defined in section 6 of the Senate bill.

Early in the debate, the Chairman of the Senate Public Works Committee, Jennings Randolph of West Virginia, offered an anendment concerning timetables and procedures for the NCAQ that assumed the immediate implementation and enforcement of the nondeterioration provision. The NCAQ was to give priority to a study of the implementation of the PSD provisions in the Clean Air Act and was required to subinit a report of its conclusions to Congress within two years. ${ }^{188}$ The report was to focus on whether the increments of change in air quality were appropriate to prevent significant deterioration of air quality in class I and class II areas. The NCAQ's authority in the area of significant deterioration, however, was to be constrained because tlie Randolph ainendment gave the EPA authority over the funds needed to support tlie NCAQ study. ${ }^{189}$ It would be directed to provide information to assist Congress in determining future air pollution programs. ${ }^{190}$ According to Senator Randolph, the NCAQ was to assist Congress im closely watching the results of its efforts. Randolph added: "We inust not forget to do this. We must monitor the prograin. We must liave the oversight hearings. We inust be very careful to see that the intent of Congress is carried out, as well as the actual language of the law."191

In debating the timetable Randolph proposed for the NCAQ study, Senator Frank Moss of Utah, an opponent of PSD, offered an ainendment that sought to delete the provision related to prevention of significant deterioration so that there would be no legislation on that subject until the NCAQ's study was complete. ${ }^{192}$ Moss's action was understandable, given that he represented a state with many class I areas (parks), and therefore sought to limit the applicability of PSD. The Moss ainendment would liave further altered the context and timetable of the reports to be submitted. Investigations were to consider the effects of "existing or proposed national ambient air quality standards," as well as the effects of any "existing or proposed policy of

187 Id.

188122 Cong. Rec. 23,961 (1976) (provision of the Randolph amendment).

$189 \mathrm{Id}$.

$190 \mathrm{Id}$.

191 Id. at 23,962 (statement of Senator Randolph).

192 Id. at $25,148$. 
prohibiting deterioration of air quality in areas identified as better than required."193 The NCAQ would be directed to submit a report of appropriate recommendations and results of studies one year after enactinent. A second report was to be submitted "with regard to all other Commission studies and investigations, together with any appropriate recommendations, not later than three years after the date of enactment" of the bill. ${ }^{194}$

The proposed Moss study would have addressed the concerns that nondegradation would have an adverse mipact on the economy and land use. The primary intent of the Moss amendment was to strike the nondeterioration proposal so that there would be no legislation until the Commission's report was complete. It was argued that the delay in legislation would provide Congress with the opportunity to obtain adequate information before arbitrarily setting emission standards. During the time the study was to be conducted, existing EPA regulations would remain in force. ${ }^{195}$ The Moss amendment was supported by the National Construction Industry Council, ${ }^{196}$ the National Rural Elect Cooperation Association, ${ }^{197}$ President Gerald Ford, ${ }^{198}$ and the Builders and Construction Trades of the AFL-CIO. ${ }^{199}$ Nevertheless, the Senate rejected the amendment by a $63-31$ vote. ${ }^{200}$

Two other Senators from areas that would have been hard hit by PSD requirements introduced similar amendments. Senator James Allen of Alabama offered an amendment to the Randolph amendment that wo.ld have provided for the enactment of the significant deterioration proposal (similar to the Randolph amendment discussed above), but would have suspended implementation and enforcement of PSD rules until one year after the Commission's report. ${ }^{201}$

In another attempt to delay PSD regulations, Senator William Scott of Virgimia proposed that "durmg the period of the [NCAQ] study ... nothing in [the Clean Air Act] shall be construed to require or provide for the estabhishment of Federal standards more stringent than primary and secondary air quality standards." 202 The Senate rejected both the Scott and the Allen amendments by substantial majorities, ${ }^{203}$ but approved the Randolph

\footnotetext{
193 Id.

194 Id.

195 Id. at 24,536 .

196 Id. at 25,150 .

197 Id. at 25,156 .

198 Id. at 25,150 .

199 Id. at 15,155 .

200 Id. at 25,192 .

201 Id. at 25,541.

202 Id. at $25,159$.
}

203 The Scott amendment was defeated by a vote of $74-17$, id. at 25,178 , and the Allen amendment was defeated by a vote of $59-23$, id. at 25,550 . 
amendment by the overwhelming margin of $83-1 .^{204}$

The House also debated the role of the NCAQ. The original House bill did not provide for such a commission, ${ }^{205}$ so Representative Paul Rogers of Florida, Chairman of the House Subcommittee on Health and the Environment, offered an amendment calling for the formation of the NCAQ. ${ }^{206}$ The Rogers amendment was similar to the Randolph amendment im the Senate in that it would have implemented the new PSD regulations and a study by the NCAQ on air quality deterioration concurrently. ${ }^{207}$

Like Senator Randolph, Representative Rogers faced a series of amendments from colleagues who sought to delay implementation of the new PSD regulations until the NCAQ study was completed. Claiming that the House proposal for new nondeterioration pohcies was based on "scanty information," Representative Bill Chappell of Florida offered an amendment-similar to the Moss amendment in the Senate-that would have left the existing EPA regulations on nondeterioration unaffected until the NCAQ study was concluded. ${ }^{208}$ Representative Chappell argued that his amendment would provide Congress and the EPA with an opportuinty to learn more about the effects of the nondeterioration proposal on the economy and the environment. ${ }^{209}$ But like the Senate, the House rejected all attempts to delay implementation of the study, and rejected the Chappell amendment by a vote of $199-156 .^{210}$ It approved the Rogers amendment by a margin of 301-57,211 and the final version of the House bill contained the NCAQ proposal. ${ }^{212}$

Ultimately, the composition of the NCAQ in the 1977 Amendments reflected a compromise between the House and Senate over which constituent group imterests to incorporate into EPA decisionmaking. As enacted, the bill provided:

Such Commission shall be composed of eleven members, mcluding the chairman and ranking minority member of the Senate Committee on Public Works and the House Committee on Interstate and Foreign Commerce ... and seven members of the public appointed by the President .... Not more than one-third of the members of the Commission may have any interest in any busmess or activity regulated

204 Id. at $25,552$.

205 See H.R. 10,498, 94th Cong., 2d Sess., 122 Cong. Rec. 29,216 (1976).

206122 Cong. Rec. 29,234 (1976).

$207 \mathrm{Id}$.

208 Id. at $29,244$.

209 Id. at 29,255 .

210 Id.

211 Id. at $29,242$.

212 Id. at 29,243 . 
under this Act. ${ }^{213}$

Interestingly, in the final version of the bill, members of Congress on the Commission did not serve ex officio, but instead had an active role in shaping the Commission's studies and recommendations. ${ }^{214}$

The focus of the 1977 Clean Air Act Amendments also reflected a compromise between the Senate and House proposals. Under the 1977 Amendments, the Commission was to focus on both emissions from mobile sources and the implications of significant deterioration. ${ }^{215}$ The Commission's jurisdiction over the issue of nondegradation, however, was severely limited by the requirement that the NAS conduct studies on the same subject. ${ }^{216}$

The debate over the creation of the NCAQ illustrates three important points. First, the composition of its membership was of critical importance, for it determined which constituents were represented and, therefore, which constituents had the ability to affect the EPA's activities through the NCAQ's study. This aspect of the NCAQ was one important difference betwecn the Senate and House provisions, with each favoring a panel that represented their interests. Second, the NCAQ demonstrated congressional intent to use studies to oversee agency activity. Again, the House and Senate differed as to the principal mission of the NCAQ, each wanting it to focus on different aspects of EPA policy. Third, the attempts to use the NCAQ to forestall the implementation of PSD rules shows how procedures, $\mathrm{m}$ this case a simple study, could be used to affect agency decisionmaking and the policies that resulted froin it.

\section{Warranties}

Another major point of controversy in the 1976 and 1977 debates was over the establishment of emission standards for mobile sources. The history of warranties for auto einissions control devices provides additional insight into the use of procedures for policy purposes, as well as the differences between the policy objectives of the House and Senate. The 1970 Amendments required automobile manufacturers to provide a warranty on pollution control devices for five years or 50,000 miles. ${ }^{217}$ Soon thereafter, it becaine apparent that manufacturers would respond by requiring that their emission control devices be maintained and repaired by their own authorized

213 Clean Air Amendments of 1977, Pub. L. No. 95-95, $\S 313,91$ Stat. 685, 787, repealed by Act of July 2, 1980, Pub. L. No. 96-300, § 1(c), 94 Stat. 831 (1980).

214 Id., 91 Stat. at 787.

215 Id., 91 Stat. at 785.

216 Id., 91 Stat. at 787-88.

217 Clean Air Amendments of 1970, Pub. L. No. 91-604, §6(a), 84 Stat. 1676, 1692 (codified at 42 U.S.C. $§ 7521$ (d)(1) (1982)). 
mechanics-for the most part the dealers who sold their cars. Not surprisingly, imdependent automobile mechanics expressed concern that by linking the warranty to dealer maintenance, they would lose a substantial portion of their regular repair business to the authorized dealers. The independent mechamics received some support from the Federal Trade Commission (FTC), which warned the EPA that the warranty provisions would be anticompetitive if they unfairly tied a car owner to the dealer who sold the car. $^{218}$

The House, ever sensitive to the concerns of any industry, responded by making three proposals in its 1976 bill. First, it limited the warranty to eighteen months or 18,000 miles, thereby shortening the period of tied maintenance. ${ }^{219}$ Second, it authorized the FTC to undertake a study of the competitive effects of its warranty requirements, thereby formally requesting that the agency elaborate on its earlier warnings to the EPA. Third, it authorized the EPA to increase the warranty to five years or 50,000 miles, but only if the FTC agreed. This gave the FTC a veto power over the EPA's decision. Moreover, it required that the EPA find that the longer warranty had "no significant anticompetitive effects."220

The Senate's actions were similar to those of the House in soine ways but not others. The Senate Public Works Committee proposed to keep the five year $/ 50,000$ mile requirement; however, it also authorized the FTC to study its anticompetitive effects. Moreover, the Committee asked the FTC to report to Congress, not to the EPA. ${ }^{221}$ But it did not allow the FTC to veto EPA decisions, nor did it set up a procedure under which the EPA could alter the terms of warranties.

In the floor debate, Senator Lloyd Bentsen of Texas proposed an amendment almost identical to the House proposal, which expressed his deep concern about "the 400,000 independent repair shops in this country, 1,700 independent parts manufacturers, and 22,000 independent parts distributors" that he beheved would be adversely affected by retaining the five year/ 50,000 mile warranty instead of adopting the eighteen month/18,000 mile warranty proposal. ${ }^{222}$ Bentsen's proposed amendment was defeated by a 51 45 vote. ${ }^{223}$

The 1977 House and Senate bills were essentially identical to their proposals of a year earhier, and so a couference committee was again called upon to resolve the dispute. The tradeoff was clear enough. Automobile manufac-

218 S. Rep. No. 717, 94th Cong., 2d Sess. 69 (1976).

219 H.R. Rep. No. 1175, 94th Cong., 2d Sess. 235 (1976).

220 Id. at 236.

221 S. Rep. No. 717, 94th Cong., 2d Sess. 72 (1976).

222122 Cong. Rec. 24,299 (1976).

223 Id. at $24,313$. 
turers could not fairly be required to give a warranty on a device that others would maintain and repair; however, an important constituency was deeply offended by the government requiring that all its customers do business with its competitors. The Senate was willing to study the issue, but in this case wanted the more stringent provision. The House wanted to allow the FTC, an antitrust watchdog, to veto any proposal for inore than a minimum warranty period. Knowing the prochvities of the FTC, which had already expressed its position on the matter, one could rationally expect that this was tantamount to enacting the weaker warranty.

Congress coinproimised on an intermediate warranty of two years or 24,000 miles. $^{224}$ Interestingly, although both the House and the Senate had passed bills requesting an FTC study, the conference report (and the 1977 Amendinents) contaimed no such provision. In addition, the bill did not require that the EPA revise the warranty requirement and, of course, did not give the FTC a veto power over such a proposal.

\section{CONCLUSION}

The theory developed in this Article focuses on the problein of controlling bureaucratic agents and has two inplications. First, it shows how an ex post legislative solution is a cuinbersome and generally ineffective tool against bureaucrats who deviate from the policies preferred by politicians. Within limits, pohticians are unlikely to be able to reverse a bureaucratic decision so long as bureaucrats deviate in a way that makes one of the inajor political actors better off than they were under the status quo. But this does not imply that the situation for politicians is hopeless. The second implication of the theory is that the main avenue for controlling bureaucrats is to place ex ante procedural constraints on the decisionmaking process. If these constraints allow politicians to respond to agency deviations prior to the agency's implementation of a change in policy, they can provide effective control over agency decisions.

We showed how administrative procedures play this critical role, and that they do so in several ways. First, by imposing a particular sequence on agency decisioumaking, they create an "early warning" system that alerts politicians (and their constituents) that an agency inay attempt to change course. Second, the process itself imposes delay, affording ample time for politicians to intervene before an agency can present them with a fait accompli. Third, procedures allow politicians to adjust the set of pressures from the environment the agency faces, and in so doing, to stack the deck in favor of certain constituents.

224 H.R. Conf. Rep. No. 564, 95th Cong., 1st Sess. 168, reprinted in 1977 U.S. Code Cong. \& Admin. News 1502, 1549. 
The Article ends with a case study of air pollution control regulation. This study shows that politicians were concerned witl procedures as a means of imfluencing agency decisionmaking througliout the 1960s and 1970s. The discussion of the court's unanticipated change in policy, in its 1972 decision in Sierra Club v. Ruckelshaus, ${ }^{225}$ slows how difficult ex post legislative changes are, and in particular, that politicians were unable to reestablish the status quo. The analysis in Part III shows that the 1977 Amendments to the Clear Air Act, the inain legislative reaction to Sierra $C l u b$, were primarily procedural. The review of the considerations of this legislation reveals low different politicians atteinpted to use procedure to benefit their own constituents. Most of these atteinpts were unsuccessful because other legislators saw that the proposed changes would thwart their own policy objectives.

225344 F. Supp. 253 (D.D.C. 1972), aff'd per curiam by an equally divided Court sub nom. Fri v. Sierra Club, 412 U.S. 541 (1973). 